\title{
From elmolo to Gura Pau: A remembered Cushitic language OF LAKE TURKANA AND ITS POSSIBLE REVITALIZATION
}

\author{
Mauro Tosco \\ University of Turin
}

\begin{abstract}
This article discusses the "extinct" Elmolo language of the Lake Turkana area in Kenya. A surprisingly large amount of the vocabulary of this Cushitic language (whose community shifted to Nilotic Samburu in the 20th century), far from being lost and forgotten, is still known and is, to a certain extent, still used. The Cushitic material contains both specialized vocabulary (for the most part related to fishing) and miscellaneous and general words, mostly basic lexicon. It is this part of the lexicon that is the basis of recent revitalization efforts currently undertaken by the community in response to the changing political situation in the area. The article describes the Cushitic material still found among the Elmolo and discusses the current revitalization efforts (in which the author has, albeit marginally, taken part), pinpointing its difficulties and uncertain results. The article is followed by a glossary listing all the Cushitic words still in use or remembered by at least a part of the community.
\end{abstract}

Keywords: Elmolo, Cushitic, language revitalization, language classification

\section{The Elmolo people today}

The Elmolo are a small fishing community living near Lake Turkana, in northeast Kenya. Long considered "the smallest tribe of Kenya" and on the verge of extinction, the Elmolo have actually been increasing in number in recent years; while less than 100 people were counted by Spencer (1973), and Heine (1980) gave their number as approximately 200, they are today approximately 700 (Otiero 2008: 5 gives their number as 613 following a headcount he personally conducted). A major role in their recent demographic history seems to have been played by the decision (in the seventies of the 20th century) to give up endogamy.

A minority lives in the District (formerly a Division) center of Loiyangalani, but the overwhelming majority inhabits two villages: Layieni $(6 \mathrm{~km}$. north of Loiyangalani), which according to the 1999 Kenya National Census counted 70 households and 363 people; and Komote (13 km. North of Loiyangalani), with 63 households and 250 people, for a total of $613{ }^{2}$

\footnotetext{
${ }^{1}$ I would like to express my gratitude to the following institutions and people, who in different ways made possible and helped my research among the Elmolo: the University of Turin, for the financial support which made possible my travel and fieldwork; the Consolata Mission at Loiyangalani, and in particular parish priest Father Andrew Ndirangu for his kind hospitality during my fieldwork in 2010 and 2012; all the Elmolo people, and in particular Michael Basili and the other members of the Gura Pau CBO, who organized my travel to and stay in Loiyangalani in July-August 2010, as well as the interviews with the elders and the collection of the linguistic data; anthropologist Dr. Alberto Salza for introducing me to the Elmolo people and for his constant assistance and the many fruitful hours of discussion, both in Loiyangalani and in Turin. Of course, all errors and omissions are my exclusive intellectual property.

${ }^{2}$ Quite surprisingly, the Kenya National Census of 2009 reports 2,840 Elmolo.
} 
Approximate geographic coordinates are: $2^{\circ} 45^{\prime} \mathrm{N}, 36^{\circ} 43^{\prime}$ E. Other Elmolo live for at least part of the year further North of Komote, especially in Palo (25 km. North of Loiyangalani), where they fish and attend to goats (no grazing being possible in Layieni and Komote).

The location of Elmolo and the neighboring languages is shown in the map below:

\section{Map. Language map of Kenya showing the location of the Elmolo language and people}

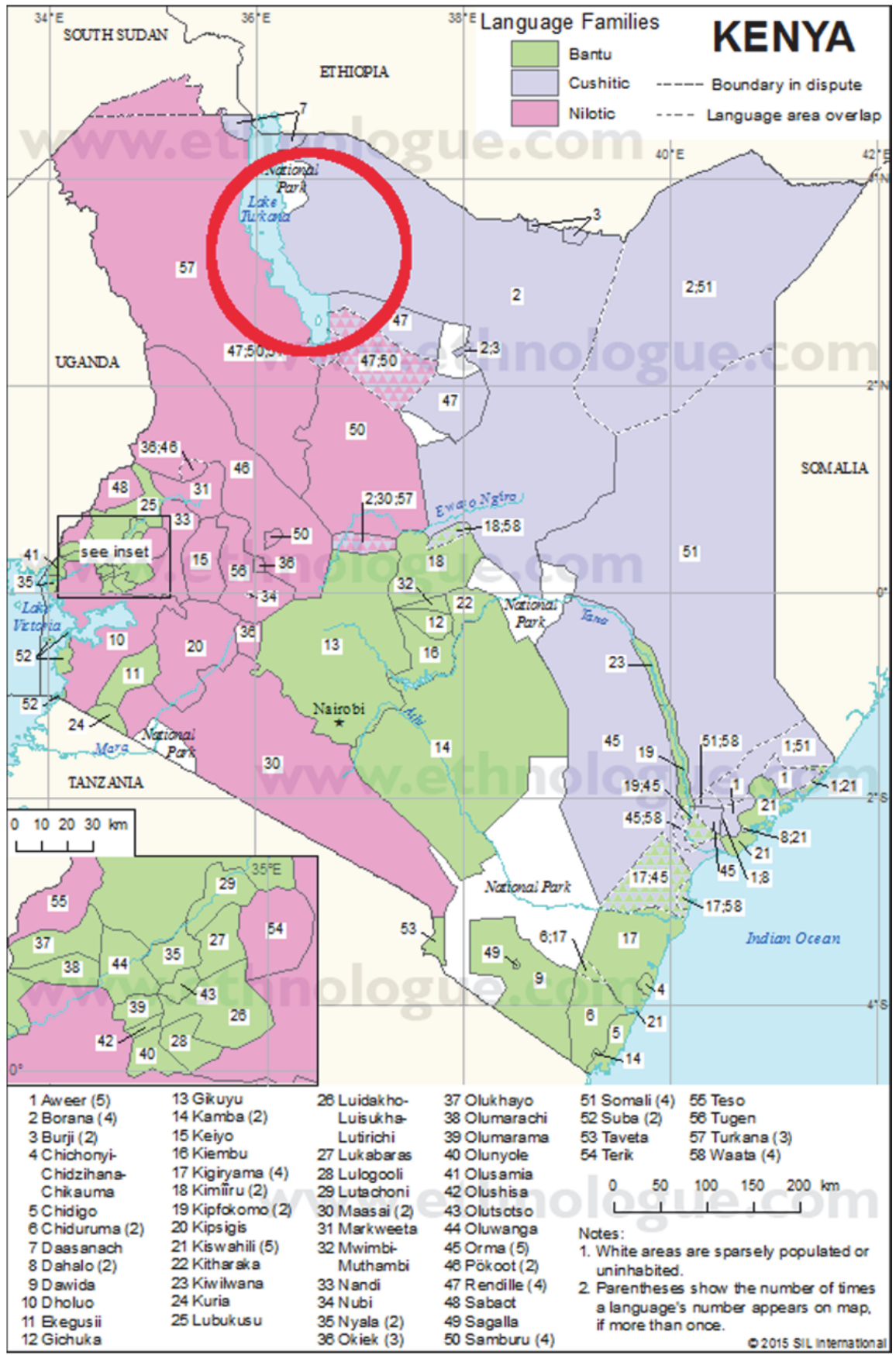


(from http://www.ethnologue.com/map/KE, with modifications)

Finally, a section of the Elmolo is settled on an island off Ileret, $70 \mathrm{~km}$. south of the Ethiopian border. Just as the southern Elmolo have shifted their language allegiance to Samburu (see below), their northern brethren have adopted Dhaasanac. According to Michael Basili (private communication), a few northern Elmolo may still know bits of the ancestral language.

Although the Elmolo still depend primarily on fishing, they have also acquired many goats and even some cattle, which are attended to by Turkana and Samburu herdsmen in the Mount Kulal area. Tourism, although occasional, is another important source of income. In terms of religion, he Elmolo are now completely Roman Catholic.

Uncertainty surrounds the very name of the Elmolo: Heine (1980: 175) states that Elmolo, preceded by the Maa article $l$-, derives from Samburu mó-lu 'this man,'. This etymology is unknown to the speakers interviewed as part of this study. Heine says further that the original autoethnonym was gúra páu 'people (of the) lake,' a denomination which has nowadays gained some currency among the community and, as will be detailed below, is also the name adopted by the cultural association of the Elmolo.

\section{The Elmolo language shift}

The Elmolo today speak Samburu (ISO 639 code: saq) as their first language, a northern Maa variety (Nilo-Saharan, Eastern Nilotic branch) especially close to Camus (or Il-Chamus) and very similar to the Maa spoken by the Maasai of Kenya and Tanzania. As a second language, most of the Elmolo know Swahili, and a few speak at least some English. Bi- and multilingualism in other languages of the area has not been checked.

Samburu was adopted during the first half of the 20th century and replaced an East Cushitic language of the Omo-Tana group, especially close to Dhaasanac (Tosco 2001) and even more so to Arbore (Hayward 1984) of Southwest Ethiopia; Elmolo forms with these two languages the Western branch of Omo-Tana; Somali and Rendille are representatives of the East branch. The classificatory position of Elmolo within the Omo-Tana subgroup of East Cushitic is shown in the following figure:

Figure. The classification of EImolo

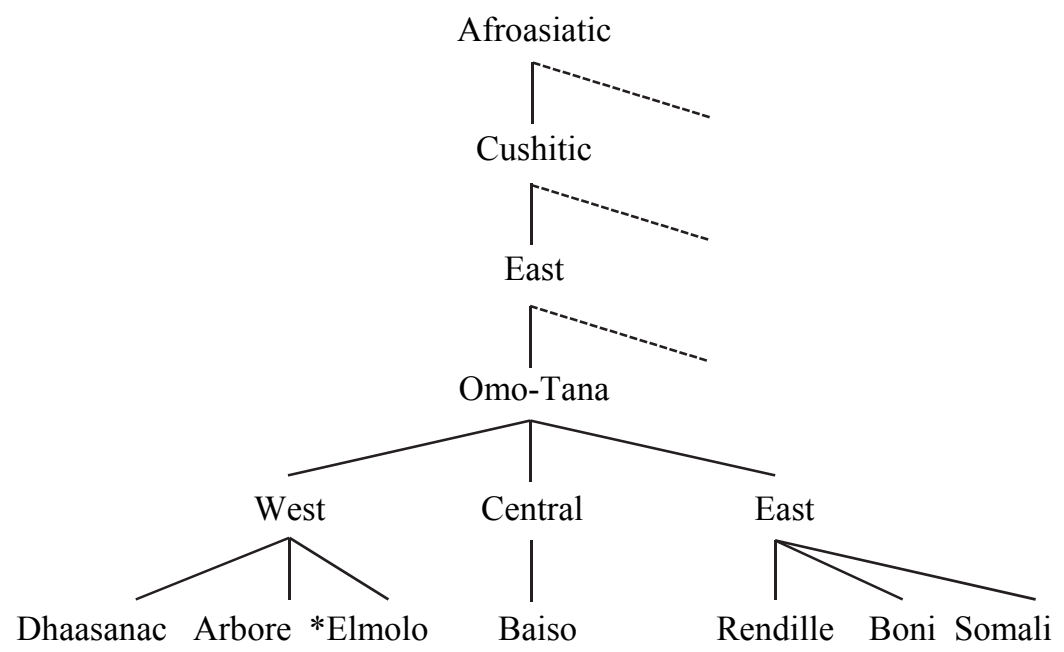


This language, commonly referred to as Elmolo (ISO 639 code: elm) is for all practical purposes extinct. According to the community, the last "good" speaker, Kaayo, died in $1999 .^{3}$

Knowledge of Cushitic Elmolo is based upon Bernd Heine's fieldwork in the 1970s and consists of a short vocabulary (Heine 1972/73) and grammatical notes (Heine 1975/76) in German, later followed, after renewed fieldwork, by a comprehensive sketch and glossary in English (Heine 1980). Elmolo appears to be a typical East Cushitic, Omo-Tana language, with SOV as basic sentence order, modifiers following their head, extensive use of gender agreement, a handful of prefix-conjugated verbs against a productive class of suffix verbs, verbal derivation centered upon a causative and a middle/benefactive extension, etc.

Sasse (1992) argued that by the 1970s the Elmolo were at best "rusty speakers," and that the data collected in a very short time by Heine contained too many irregularities and gaps to be considered representative of "true" Elmolo. Sasse's doubts have been more recently substantiated by Tosco (2012) on the basis of an analysis of the Elmolo verbal paradigms in comparison with those of its "healthy" northern relatives, Dhaasanac and Arbore.

Heine (1980) and later Brenzinger (1992) reconstructed the history of the Elmolo language shift, essentially as a by-product to the adoption of Samburu's cultural values. According to them, the Samburu were in contact with the Elmolo in the late 19th century as part of a larger movement of populations, itself caused by a series of major bovine epidemics. A Samburu group sought refuge among the Elmolo in a period of famine, only to return to a pastoral way of life as soon as cattle were available again. Nevertheless, cultural assimilation to the Samburu had been set in motion and, by the 1930s the Elmolo had made a conscious decision to stop transmitting their language to the new generations and to adopt Samburu. Together with the language, they also acquired a number of Samburu cultural traits and values, such as male circumcision, but were unable - or unwilling - to shift to pastoralism.

It seems that Heine's account is too simplified, and telescopes a number of changes occurring over a longer span of time. Scherrer (1978), for example, points out that many cultural traits (such as ritual ceremonies) were adopted recently (as late as the 1950s) amid much controversy in the community. It is also a fact that the Elmolo do not consider themselves Samburu (nor are they considered as such by the Samburu) and do not refer to their language as Samburu, while are keen at the same time to point out differences from "common" Samburu in their own variety, the "Elmolo-Samburu" investigated in Brenzinger (1992).

\section{How many language shifts?}

An unsolved question is whether the Elmolo were "originally" speakers of a Cushitic language, and still another is whether they were always fishers or rather pastoralists who turned to fishing out of necessity in an area utterly unsuitable to animal husbandry. Heine (1982) favors the first hypothesis, and claims that 'traditional fishing in Kenya's Rift Valley is likely to go back to Eastern Cushites originating from the Ethiopian Highlands' (Heine 1982: 36). He further proposes to connect this ancient (original?) layer of population to the Namoratunga culture of the first millennium B.C. This fishing population spoke a Cushitic language which Heine, Rottland and Vossen (1979) labeled Proto-Baz (from the reconstructed word for 'lake,' pau in Elmolo) and

${ }^{3}$ A photograph of Kaayo walking along the shore of Lake Turkana is found in Quattrocchio (n.d.), a trilingual English, Italian and German booklet published by the Consolata Fathers in Nairobi. 
which in due time came into contact with Nilotic invaders, becoming the source of a sizable number of Cushitic loans in Southern Nilotic.

While the presence of Cushitic words in Southern (and Eastern) Nilotic is a fact, there is scarcely any specific evidence (other than geographic proximity) linking these loans to any fishing community in the Lake Turkana area and to the Elmolo in particular. Moreover, the technical vocabulary (fish names, fishing implements, and techniques) which make up the bulk of the Elmolo language as remembered today by the community (see below), while certainly not Samburu, does not point to any wider Cushitic connection either (the widespread traditional Cushitic taboo on fish by many Cushitic peoples does not help in finding Cushitic cognates to much Elmolo vocabulary). In short, the lexicon of Cushitic Elmolo is largely "idiosyncratic" precisely because it is tied to fishing culture.

A different view on the hunting-gathering and fishing communities of East Africa sees them as largely marginal groups, and often as former pastoralists who were forced to adopt a despised way of subsistence after having lost their cattle as a result of war or epidemics. Such a view receives further support by the observation that the marginal, outcast groups of East Africa are constantly renewed and enriched through the influx of genetic (and linguistic) material coming from neighboring peoples: apart from the devastating effects of famines and wars, individuals (men, women or children) may and often are cast off from their group for a number of reasons, mainly having to do with the violation of group solidarity and codes (cf. Stiles 1988 on the Boni of the Kenyan coast).

The Elmolo ideally bridge these two opposing views: on the one hand, they have myths of origins which portray them as the original inhabitants of the area - the only true "People of the Lake". But they are also quite adamant about being a "collection" of different lineages interwoven together by a common way of life, with sections coming from different neighboring peoples: the Rendille, the Borana, the Samburu, etc. This belief does not seem in itself a major proof in favor of any specific view on their origin, as such a claim is widespread in the area.

Whatever their origin, it seems certain that a prominent role in the ethnolinguistic history of the Elmolo was played by the Marle, one of the Elmolo clans but also one of the two groups (together with the Gondorobba) who make up the Arbore of Ethiopia (Hayward 1984: 4). According to the Elmolo (Otiero 2008: 5), the Marle came from Ethiopia and settled in Alia Bay (along Lake Turkana, south of the present-day Ethiopia-Kenya border). Later, a group headed back North and became the Arbore, while another went South and settled in Moite (a sacred mountain of the Elmolo north of their present-day location).

Bassi (2011) reconstructs the earlier history of the Marle placing them originally in the Mount Kuraz area (presently along the border between Ethiopia and South Sudan), among the Elelle (presently a section of the Dhaasanac) and the Karo (who nowadays speak a variety of Hamer, South Omotic). In the first half of the 19th century, all of these peoples would have split and migrated under the pressure of people coming from the South, mainly the Turkana and the Shir. The latter, who are today the dominating group among the Dhaasanac, would have absorbed the Elelle and taken up their speech, yielding the Dhaasanac language. Independently, and on a strictly linguistic basis, Tosco (2007) suggested that certain structural features of Dhaasanac - for example, the sheer amount of irregularity involved, e.g., in the verbal system - may be explained

\footnotetext{
${ }^{4}$ A few Elmolo myths of origins have been collected by anthropologist Alberto Salza and are available in Italian and English transation in the website http://carcreff.free.fr/elmolo/pages/flat-tab-short_index_it.html
} 
as the result of imperfect language acquisition on a societal scale, followed by analogy and paradigm regularization.

The Marle would have reached other groups in the Lake Stephanie (Chew Bahir) area and given rise to the Arbore, while a group of Marle would have stretched as far south as the lower end of Lake Turkana, where they mingled with local groups of fishermen, giving them their language and forming the Elmolo people.

Salza (forthcoming) collected local traditions about a group of Marle crossing through the Dhaasanac-land around the 1880s, moving south into the Lake Turkana area and settling among the local fisher folk, thus giving rise to the Elmolo. In this view, the East Cushitic language spoken by the Elmolo before they shifted to Samburu in the 20th century would actually have been Marle.

Both Bassi and Salza's views neatly explain the linguistic connection between the Dhaasanac, the Arbore, and the Elmolo - all three of them being offshoots of the Marle language. Fascinating as these hypotheses may be, they seem to suffer from too limited a time window. It seems improbable that the Elmolo would have adopted the Cushitic language of the Marle not earlier than the late 19th century, just in time to jettison it and adopt Samburu in the first half of the 20th.

Furthermore, as the following sections will show, the shift to Samburu is not the end of the story, as even today the Elmolo language is far from completely dead and forgotten.

\section{Elmolo remembered}

Compared to other cases of language shift, the Elmolo case is interesting for the considerable quantity of preserved vocabulary. The original Cushitic-Elmolo lexicon still used or remembered by the Elmolo can be divided as to,

- items belonging to the basic vocabulary (body parts; kinship terms; numerals; names of animals and plants) and not necessarily belonging to the cultural vocabulary;

- cultural vocabulary belonging to semantic fields for which the Samburu language provided no ready equivalent, and which has been grafted onto the new language of the community. This refers first and foremost to fishing activities, and ranges from names for fish and fish parts to names of fishing implements and techniques. This part of the old Elmolo lexicon is still part of the everyday speech of the Elmolo.

Fishing vocabulary in the area was collected and discussed by Heine (1982) with an eye at reconstructing previous population movements in the Lake Turkana area; it is further discussed in Brenzinger (1992) as to the peculiarities of the Samburu dialect spoken by the Elmolo. Our own lexicon (see Appendix) contains many items which went unmentioned in previous sources (others are apparently no longer in use, have a different meaning or were unknown to our informants), but probably many more still waiting to be recorded.

More difficult is assessing the extent and use of the basic vocabulary. It is certainly not used in everyday life, where conversation is carried on exclusively in Samburu. It has rather always been a lexical niche shared to different degrees by the elders and a few grown-ups, with meanings and forms often debated and contested and a huge amount of variation between speakers. Within the current revitalization efforts (see Section 6) it is spread to younger Elmolo.

All in all, out of the 633 items in the (certainly incomplete) list in the Appendix, 
- only 219 items (35\%) are found in Heine's and Brenzinger's data ${ }^{5}$ (among of course many more items which have apparently disappeared);

- of the remaining 414 items, 228 (36\%) have been collected by the author in 2010 and 2012, and

- 186 (29\%) are listed in either Omondi (2008), Omondi and Otieno (2008), and/or Lengosira and Lenapir (2010) and have been confirmed by informants.

\section{Cushitic Elmolo: what got lost and what remains}

All the Cushitic material lost its original phonology and morphosyntax and has been adapted to Samburu, or better to the Elmolo dialect of Samburu succintly described in Brenzinger (1992). ${ }^{6}$

Number and gender coding on nouns has been dropped, and not infrequently the "wrong" (from a Cushitic perspective and according to the sources) form has been preserved. Thus, the only form for 'woman' is saale, corresponding to Heine's (1980: 218) sáále, but its suppletive collective hékel is unknown. Instead, against ilik 'tooth,' Pl. ilk-o (as per Heine 1980: 206), only the plural ilko has been retained.

Only a few Cushitic plurals have been recorded:

- $\quad$ il 'eye,' Pl. inna (Heine 1980: 206 recorded $i l$ and ínna)

- inite 'egg,' Pl. inno (Heine 1980: 206 recorded iní-te, Pl. inno

- kunuf 'nail; peer group,' Pl. kunufo (Heine 1980: 213 has kúnuf, Pl. kúnúfó ‘fingernail').

In all other cases, the Samburu plural affixes $-\hat{i n}$ or $-(n) i$ are used for loanwords from Cushitic Elmolo. In this regard, it is to be noted that present-day Elmolo fully accords to Samburu morphophonemic rules: in particular, Samburu vowel harmony rules apply, and the nominal plural suffix $-(n) i$ causes closing of any open vowel in the stem. The rule was irregularly applied in Heine (1982), with such examples as pécs 'tail of crocodile,' Pl. pécsí (against expected *péesi). This seems to imply an increasing mastering of Samburu morphophonemics and the loss of specific traits of the Elmolo-Samburu variety discussed by Brenzinger (1992).

The rich Cushitic verbal morphology is generally shunned; in a few occasions, Imperative Singular forms of verbs have been recorded, but the Plural is unknown. Among the preserved verbal forms, sometimes recorded with a preceding nominal phrase (and thereby preserving the original, Cushitic SOV word order), we find:

- nuum aam 'eat the food!'; also: yaam, which actually is the Imperfect stem;

- pice iik 'drink the water!'

- peytc koon 'bring the fish!'

- may 'come!' (an irregular Imperative Singular, for which Heine (1980: 190) has má-ac;

- soo karsis (and karis) 'cook the meat!' (Heine 1980: 206 has only káris; both are Causative forms of kar 'to boil, cook (intr.)', widely attested in East Cushitic);

\footnotetext{
${ }^{5}$ Brenzinger (1992) contains a good number of items not mentioned by Heine, but only one (tamots 'small tilapia') has been accepted by our informants.

${ }^{6}$ The transcription is phonological; the following conventions are used: $\left.\left.\langle\mathrm{c}\rangle=/ \mathrm{g} /,<\mathrm{j}\right\rangle=/ \mathrm{d} /,<\breve{\mathrm{s}}\right\rangle=/ \mathrm{g} /$ (an allophone of $/ \mathrm{f} /$, as is the case in all Maa dialects, Samburu included), $<\mathrm{y}\rangle=/ \mathrm{j} /$. Voiced stops are slightly implosive. Vowel length (contrastive in Cushitic Elmolo) is marked when consistent among speakers.
} 
- pice na yardu 'fetch me water!' (a verb unknown in Heine 1980). na has been recorded on a number of occasions, apparently always with the meaning of 'to me', as in waak pice na=si 'God gave me water.' Cushitic would rather understand the meaning 'us' - cf. the 1st Plural object pronoun Ponó of Arbore (Hayward 1984: 215), Dhaasanac ní (Tosco 2001: 211), Somali (i)na, and their cognates all over Cushitic and beyond.

As is the case with nouns, Cushitic Elmolo verbs belonging to cultural domains (mainly fishing) are in everyday use, but with Samburu morphology.

In Cushitic, the (positive) Imperative Singular form of any verb is usually segmentally identical to its plain stem and can act as its citation form. In the short list which follows and in the Appendix, verbs are likewise reported in their Imperative Singular form as given by consultants. A few such verbs belonging to the fishing domain are:

- ailila 'to fish standing on the raft and using a harpoon';

- ajia 'to fish at moonlight';

- anafe 'to float';

- armarita 'to round up the ends of the net while fishing';

- artunda 'to swim on the surface'.

As evident from the phonological shape of these and many other forms, they possibly contain frozen morphological material; foremost among them is the prefix $a r$, called "Ventive" by Heine (1980). It is equivalent to Arbore ?ár, identified as a a 'verb preposition' indicating 'movement towards the speaker when the verb is an intransitive verb of motion, and movement or activity directed towards the logical subject of the sentence with other types of verb' (Hayward 1984: 310).

In a very few cases a "fully Cushitic" 3rd Singular form has been recorded:

- $\quad$ cyte ini=yaam-a 's/he is eating the fish'

The form ini=yaam- $a$ follows what we know of Elmolo grammar from Heine's description as far as the Perfect 3rd Singular Subject clitic $i n i=$ is concerned, but with an Imperfective meaning; the verb likewise carries the Imperfect 3rd Masculine affix $-a$. As any expression of morphological gender has been lost, the verbal form can be used for either a masculine or a feminine subject. Moreover, 'to eat' is one of the seven prefix-conjugated verbs in his description. According to Heine, we would expect either iní=yom 'he ate' or $i=y$ áám- $a$ 'he is eating.' In short, the old Perfective and Imperfective forms have been blended on the basis of a (historically non-existent?) stem *yaam-.

The form $i n i=$ is further featured in the only instance of a public use of written Elmolo that I am aware of: a signpost at the entrance to a small tree nursery found in the min ("house") section of the island in front of the village of Layieni. There the Gura Pau Community Based Organization (see below) is trying to cultivate acacias using the strongly alkaline water of the lake; the Elmolo word inidit, together with its English translation as 'it is possible,' is written on a tin signpost. The Elmolo word follows again the pattern of assigning to a 3rd Singular the "prefix" ini=, followed by a hitherto unrecorded verbal stem *dit- (s. Picture 1). 
Picture 1. Signpost with Elmolo word

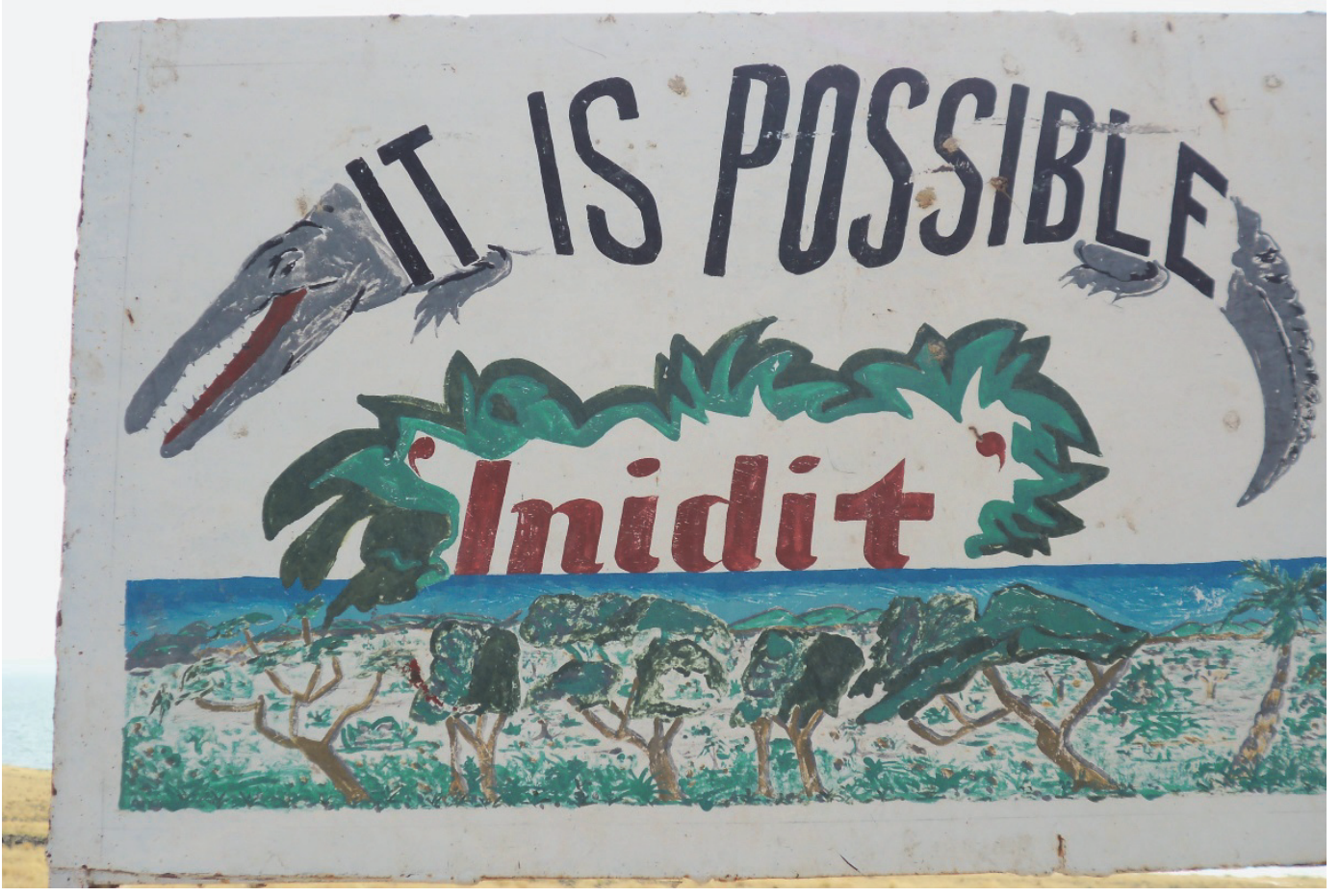

Short sentences (basically made up of a noun plus a verb in the imperative) are used on a number of occasions, most typically ritual ceremonies. Typical sentences are: ${ }^{7}$

- waga si 'give (us), God!'

- pice arsi 'provide water!'

On the other hand, speakers have quite clear opinions about what belongs to "Elmolo" and what does not: whatever does not look like Samburu is Elmolo; anything with a correspondence or even a similarity to Samburu, does not. The word báha 'bow' reported by Heine (1980) was rejected by my informants as a "good" Elmolo word because it is found in Samburu, too. The fact that it has good Cushitic connections (and a cognate inter alia in Arbore bah (Hayward 1984: 345)) obviously does not bear on the issue. On the other hand, a neologism (onomatopoeic in origin?) such as ntikitiki 'car, motor vehicle' counts as Elmolo because, we are assured, is unknown to the Samburu.

\footnotetext{
${ }^{7}$ I thank Roberto De Luca, a Master's student in Cultural Anthropology at the University of Turin, who gave me access to the recordings he made during his fieldwork among the Elmolo in Summer, 2011.
} 


\section{Attempts at revitalization}

In 1995 the "Elmolo Development Group" (EDG) was established "to promote self-reliance among the Elmolo people through responsible utilization of the resources of Lake Turkana' (Omondi 2008: 3). In the same year was launched a "Voluntary Child Sponsorship Programme" in order to sponsor higher education among the Elmolo. In 2000 the EDG changed its name to "Gura Pau Community Based Organization" (CBO), which 'is basically involved in projects empowering the Elmolo. It is under such initiatives that the Elmolo language revival program was begun' (Omondi 2008: 3).

Founder and chairman of the Gura Pau CBO is Michael Basili. A long-time teacher and later schoolmaster and Education Officer of the Loiyangalani Division, Basili retired in 2006. His dream had been to reinstate Elmolo as the language of the community through school teaching. As early as the eighties he started collecting lexical items from the elders, as illustrated in Picture 2. Many of his entries seem forgotten today or their meaning is disputed, so that even Basili himself could not vouch for their correctness. ${ }^{8}$

Picture 2. A page from Michael Basili's notebooks

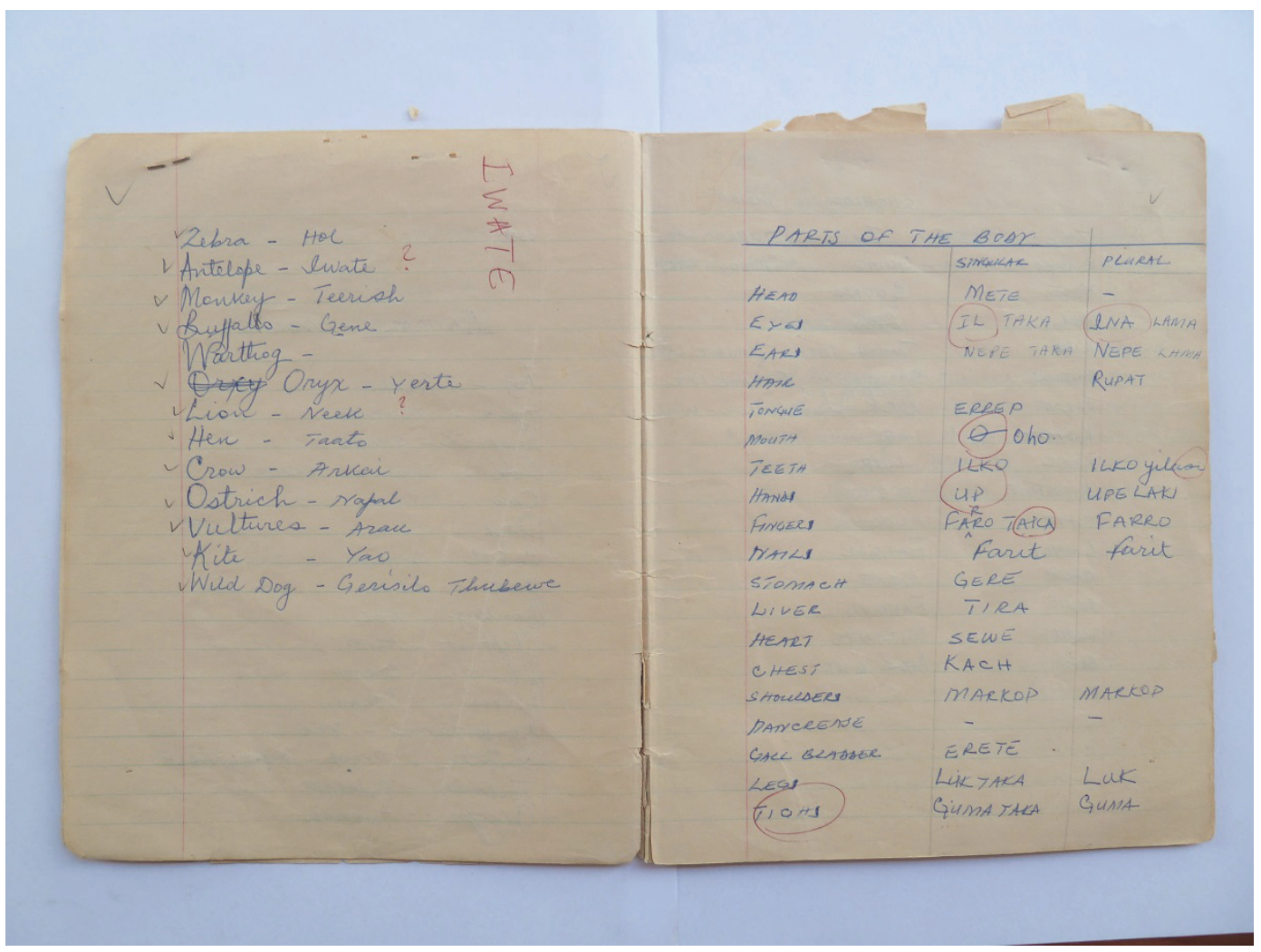

${ }^{8}$ As in other dubious cases, such entries are not listed in the Appendix. 
Within the framework of the Gura Pau CBO, and with the sponsorship of the Christensen Fund (2007-2010), Basili and his associates could start collecting further linguistic and anthropological data. This resulted in a few unpublished works: Odero Erick Omondi (University of Nairobi), assisted by Odero Isack Otieno and members of Gura Pau CBO, created a 39-pages booklet The reconstruction and documentation of the Elmolo language (Omondi 2008), and Omondi and Otieno together prepared a 20-page Elmolo-English Dictionary (Omondi and Otieno 2008), later revised by the CBO (Lengosira and Lenapir 2010).

Omondi, Otieno and the whole CBO seem to have been unaware of previous linguistic work on Elmolo - Heine and Brenzinger in particular (nor do the Elmolo have any memory of Heine's visits in the 1970s). Omondi (2008) reports on the Gura Pau CBO and comments on the language and the community: 'the Elmolo language does exist to a small extent among the Elmolo people [...] in disjoined words, basically nouns, which cannot be used in strings such as sentences or phrases by the speakers' (Omondi 2008: 4); at the same time, 'the Elmolo language is dead with just about eight elders who are able to remember some words, especially nouns [...] Consequently, sentence construction was made nearly impossible, hence lost' (Omondi 2008: 11). As a result, Omondi gives VSO as the basic sentence order of Elmolo (the same as Samburu), instead of Cushitic SOV. Other linguistic notes (on tones and vowel length) are tentative.

Omondi reports on the presence of 'Elmolo users' further north in Ileret (Basili later travelled to the area and reported that ethnic Elmolo among the Dhaasanac remember at most bits of the original language), and, strangely enough, among the Arbore (Omondi 2008: 4). After general recommendations on the necessity of further work, Omondi (2008: 14-30) provides a thematic glossary (Counting, Body Parts, Natural Phenomena, etc.) and ends with the questionnaires administered to informants. Omondi and Otieno (2008) expand the Elmolo vocabulary with 380 entries. ${ }^{9}$ Further material was provided by Lengosira and Lenapir (2010).

All this material was checked by me with Elmolo consultants, ${ }^{10}$ individually or collectively. Although my consultants were mostly the same as had been working with Omondi and Otieno, a sizable number of the entries in Omondi (2008), Omondi and Otieno (2008), and even Lengosira and Lenapir (2010) were rejected as mistaken in meaning or, more usually, unknown. ${ }^{11}$ This is probably the result of data collecting with different informants.

In 2010, Basili was struck by the strong similarity between Arbore and Elmolo when he consulted Hayward's (1984) description of Arbore. He likewise noticed the weaker similarity between Elmolo and Dhaasanac. The idea of having Arbore speakers come from Ethiopia in order to teach their language was also entertained, as well as having the community learn Elmolo on the basis of Heine's (1980) English sketch.

The less ambitious task of developing a Samburu-Elmolo mixed code was likewise put forward and tested, as it was deemed sufficiently different enough to signal distance from the neighboring communities and thereby to strengthen Elmolo identity. The basic idea was to insert as many

\footnotetext{
${ }^{9}$ Compounds are listed as separate entries: thus, salau au mete ('wife to eldest maternal uncle'), salau au nina ('wife to youngest uncle'), and salau gute ('wife to elder paternal uncle') make up three entries: Similarly, after tomon 'ten,' six other numerals are found (e.g., tomon afur 'forty,' tomon lam 'twenty,' etc.). A few other items are simply repeated; thus, kunuf 'nail,' and kunufo 'nails' are each reported twice.

${ }^{10}$ Main consultants were Michael Basili, Vivian Lenapir, Carlo Lenapir, Daniel Lokilekui, and Julius Loyok Akolong.

${ }^{11}$ All the remaining items are listed in the Appendix.
} 
Elmolo lexical items as possible within a Samburu sentence, while keeping the Samburu grammar and syntax.

Efforts with this "Elmolo-Samburu" secret code (reminiscent of the Ma'a language of the Mbugu in Tanzania, with Cushitic lexicon and Bantu morphosyntax (Mous 2003)) had been dropped by 2012, either because it was too difficult to implement or because the extant Cushitic lexical material was too limited and its knowledge too unevenly spread among the community to be of any help.

At the societal level steps have been taken to draw and print cardboards of items from Elmolo daily life in order to teach the extant Elmolo vocabulary, especially to children. Following our fieldwork in 2010, alphabet charts with color pictures were printed in Nairobi with color pictures taken from the web (and some mistakes).

Picture 3. Elmolo alphabet chart hanging in Michael Basili's office.

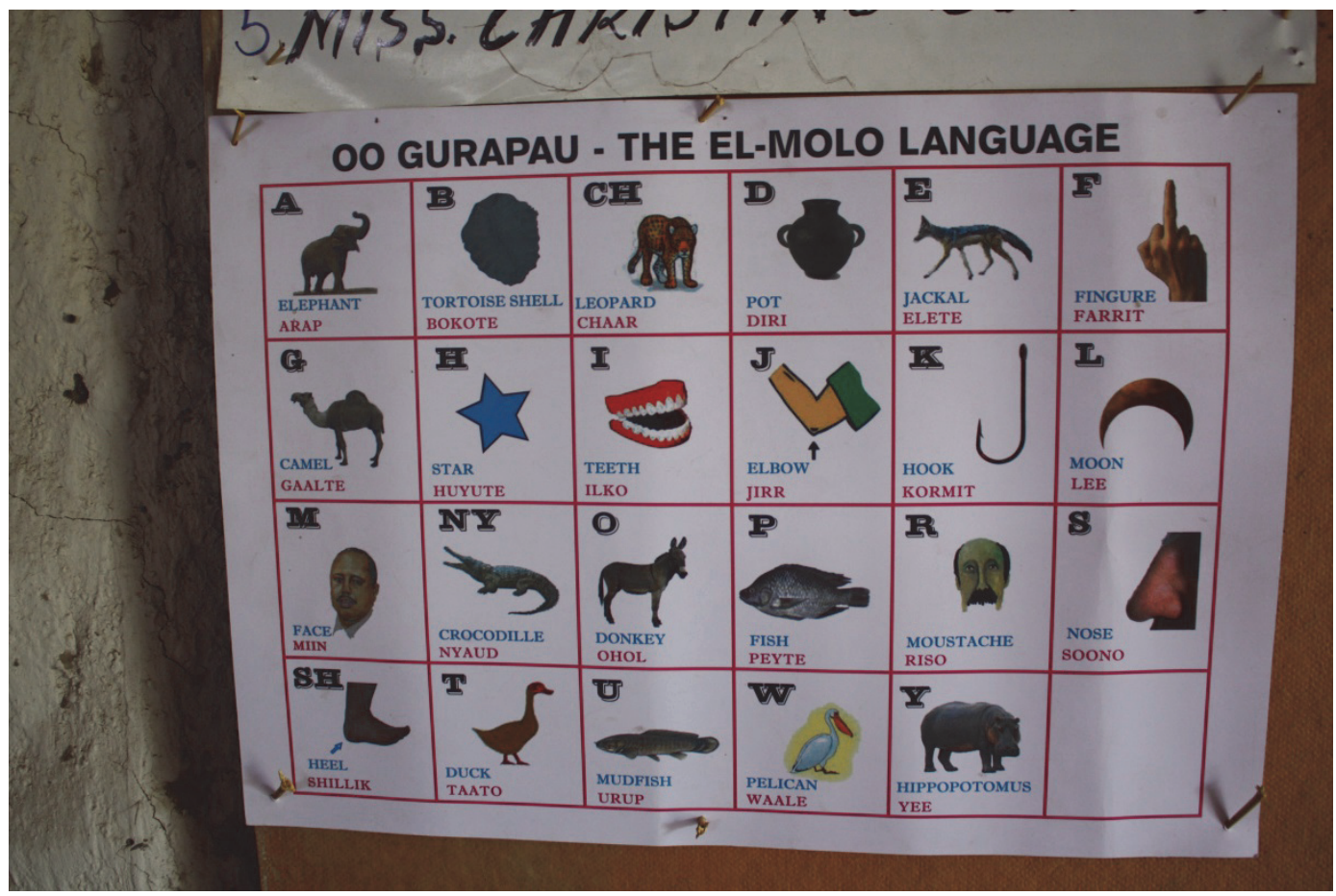

It will be noted that $<\mathrm{n}>$ was accidentally dropped from the chart. Also, one could take exception to taato as 'duck' when really means 'Egyptian goose' (Alopochen aegyptiaca). But there are more serious shortcomings: the word for 'star' was recorded as kuyyu (as in the Appendix), and I suspect that huyute was taken directly from Heine (1980). Reverence for the written word and the desire to enrich the vocabulary of an endangered or extinct language with as many items from the past as possible are of course attitudes all too common in revitalization efforts around the world (cf. many articles in Brincat, Boeder and Stolz (2003) and ó Riagáin and Stolz (2004)). Instead of using the varying and incomplete common lore of the community, the 
Gura Pau OCB has apparently chosen here the easy way of relying on a presumed authoritative written source. ${ }^{12}$

Elmolo, relabeled "Oo Gurapau”, i.e. 'Gurapau language', is written in the Latin script, basically following the Swahili orthography in the use of $<\mathrm{ch}>$ for $/ \mathrm{t} /,<\mathrm{j}>$ for $/ \mathrm{d} z /,<$ ny $>$ for $/ \mathrm{n} /$, $<\mathrm{sh}>$ for $/ \mathrm{j} /$, and $<\mathrm{y}>$ for $/ \mathrm{j} /$. Long vowels are erratically and occasionally written by doubling a vowel letter. The velar nasal $/ \mathrm{y} /$, of suspect phonological status, is written $<$ ng $>$, while the distinctions between the tap and the trill of Samburu (usually transcribed $/ \mathrm{r} /$ and $/ \mathrm{rr} /$, respectively) and $[ \pm \mathrm{ATR}]$ vowels are simply left unmarked.

Oo corresponds to Heine's (1980: 208) óho 'mouth' (and 'language') and is etymologically connected to Arbore ?ohó and more distantly to Somali af, etc. One will note again the evident purist attitude involved in the choice of oo gura pau rather than, for example, oo elmolo.

Thematic charts (for fish parts - shown in Picture 4 -, body parts, house implements, etc.), as well as separate letter charts (Picture 5) have also been printed. Needless to say, uncertainty and debate about the exact meaning of many words remain.

Picture 4. Thematic chart: the parts of a fish

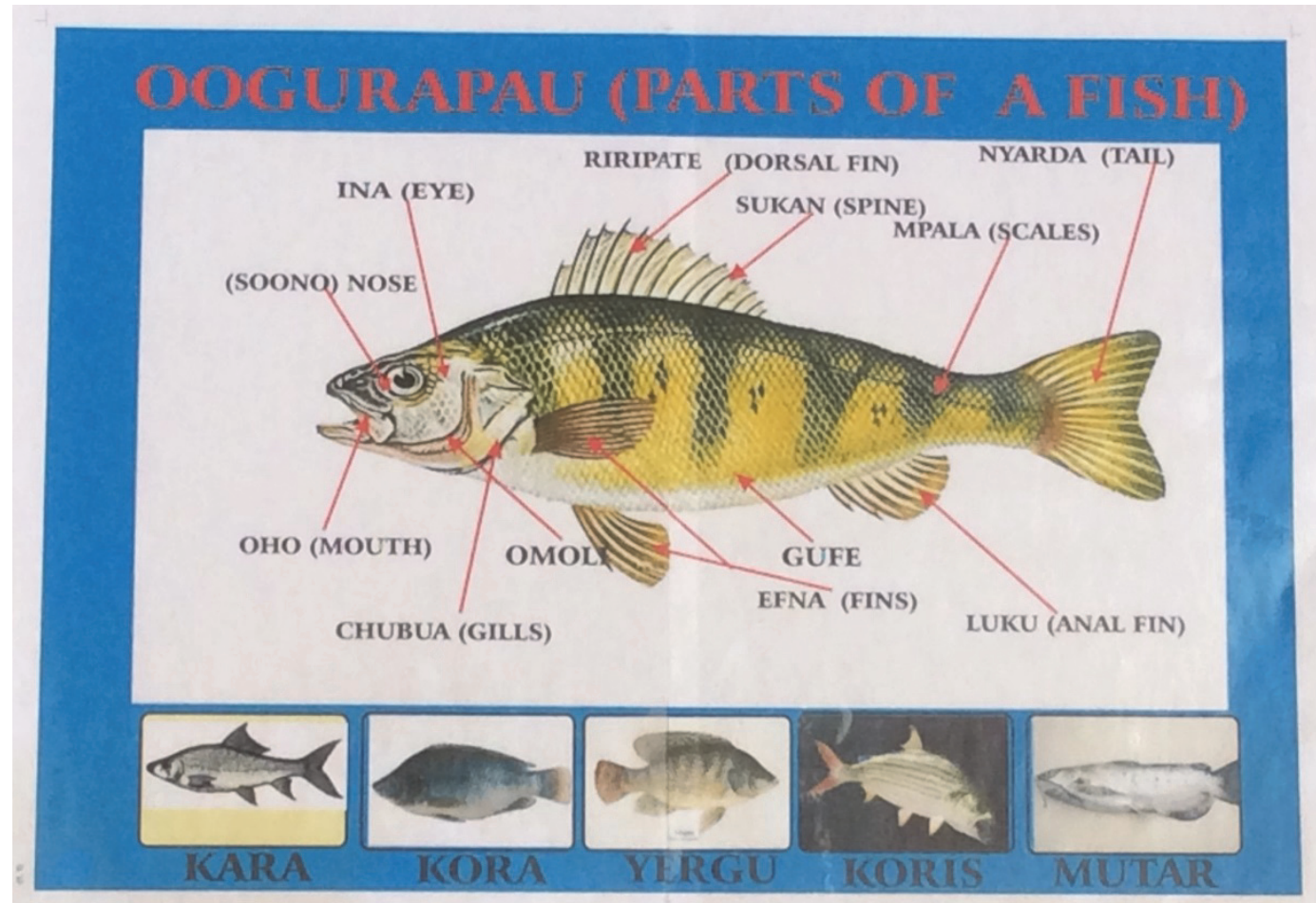

\footnotetext{
${ }^{12}$ Basili possesses copies of both Heine's (1980) sketch of Elmolo and Hayward's (1984) Arbore grammar.
} 
Picture 5. An Elmolo letter chart

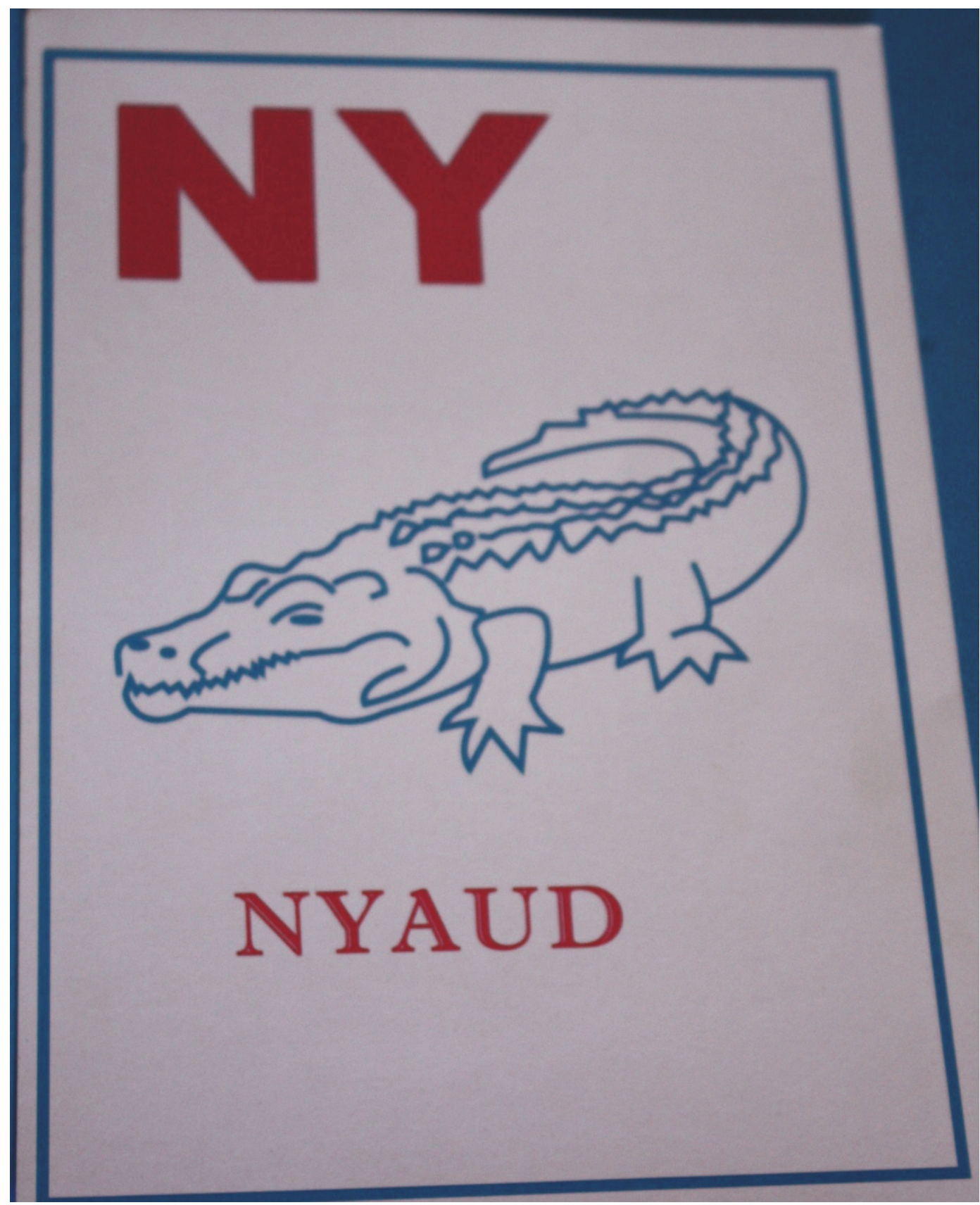

The privately funded, Turin-based Elmolo Renaissance Project, aiming at the 'Cultural Rehabilitation and Participatory Architecture among the El Molo of Lake Turkana' is currently working on school texts for the primary school level with a modicum of Elmolo lexicon selected from the vocabulary presented in the Appendix. 


\section{The wider picture and some preliminary conclusions}

The current revitalization efforts certainly have more down-to-earth and practical reasons than simple love for a lost language and a precious identity marker.

With the current dwindling of the Samburu role along the southeastern shore of Lake Turkana, and the corresponding ascendance of the Turkana (originally settled on the western side of the lake only), the status of the Samburu language is likewise on the wane. The Turkana are the most important players now, both economically and politically. For the small, traditionally neutral and unarmed Elmolo with very few exterior signs of ethnic identity, small changes in language may be a way to establish distance from the Samburu. Doing so allows them to avoid taking sides in the ongoing political (and often armed) struggles of their more powerful neighbors, to guarantee their neutrality, and to assure their fishing rights (especially since the Turkana have taken to fishing with powerboats).

This state of affairs will probably boost the Elmolo revitalization efforts; whether they will be effective remains an open question. While the stated dream of Basili and the Gura Pau CBO is the full revitalization of Elmolo, the difficulties inherent in this goal may not have been fully recognized. For one thing, it is not clear that the goal of teaching young Elmolo words of the ancestral language, will succeed even as a token of pride and self-distinctiveness. The young may ask how these words are meant to be used, if at all? They are certainly memorized, but they cannot be used in a sentence without having recourse to Samburu grammar - which, as seen above, the community does not like or is unable to do.

Success will hinge on many linguistic and extralinguistic factors, paramount among them a modicum of standardization and the establishment of Cushitic Elmolo as an identity marker. Many other key elements, however, remain out of reach of the Elmolo: ecological and economic sustainability in the Lake Turkana area, and open and free relations with the neighboring communities as well as across the Ethiopian border (with the Arbore in particular) being foremost among them. What we are witnessing is just the beginning of a, hopefully long and in the end successful process.

\section{References}

Bassi, Marco. 2011. Primary identities in the lower Omo valley: migration, cataclysm, conflict and amalgamation, 1750-1910. Journal of Eastern African Studies 5/1. 129-157.

Brenzinger, Matthias. 1992. Lexical retention in language shift: Yaaku/Mukogodo Maasai and Elmolo-Samburu. In: Matthias Brenzinger (ed.), Language Death. Factual and Theoretical Explorations with Special Reference to East Africa, Berlin and New York: Mouton de Gruyter. 213-254.

Brincat, Joseph, Winfried Boeder and Thomas Stolz (eds.). 2003. Purism in minor languages, endangered languages, regional languages, mixed languages (Papers from the conference on 'Purism in the age of globalization', Bremen, September 2001). Bochum: Universitätsverlag Dr. N. Brokmeyer.

Hayward, Dick. 1984. The Arbore Language: A First Investigation. Hamburg: Helmut Buske. 
Heine, Bernd. 1972/73. Vokabulare ostafrikanischer Restsprachen. Teil 1: Elmolo. Afrika und Übersee 56/4. 276-283.

Heine, Bernd. 1975/76. Bemerkungen zur Elmolo-Sprache. Afrika und Übersee 59/4. 278-299.

Heine, Bernd. 1980. Elmolo. In: Bernd Heine, The Non-Bantu Languages of Kenya ("Language and Dialect Atlas of Kenya 2"), Berlin: Dietrich Reimer. 173-218.

Heine, Bernd. 1982. Traditional Fishing in the Rift Valley of Kenya: A Linguistic Survey. Sprache und Geschichte in Afrika 4. 7-40.

Heine, Bernd, Franz Rottland and Rainer Vossen. 1979. Proto-Baz: Some Aspects of Early Nilotic-Cushitic Contacts. Sprache und Geschichte in Afrika 1. 75-91.

Lengosira, Andy [: Andrea] and Vivian Lenapir. 2010. Elmolo-English Dictionary, Corrections and Additions. Unpublished Ms.: $15+8$ unnumbered pages with $\mathrm{B} / \mathrm{W}$ drawings.

Mous, Maarten. 2003. The Making of a Mixed Language: The Case of Ma'a/Mbugu. Amsterdam: John Benjamins.

ó Riagáin, Dónall and Thomas Stolz (eds.). 2004. Purism: Second Helping (Papers from the conference on 'Purism in the age of globalization', Bremen, September 2001). Bochum: Universitätsverlag Dr. N. Brokmeyer.

Omondi, Odero Erick (assisted by Odero Isack Otieno, Lengosira Andrea, Lengutuk Asunta and Akolong Joseph). 2008. The reconstruction and documentation of the Elmolo language. Unpublished Ms.: 39 pages.

Omondi, Odero Erick and Odero Isack Otieno (with Lengosira Andrea, Lengutuk Asunta and Akolong Joseph). 2008. Elmolo-English Dictionary. Unpublished Ms.: 20 pages.

Quattrocchio, Giuseppe. No date. El Molo. Nairobi: Consolata Fathers.

Salza, Alberto. forth. La storia costruita. Ms.

Sasse, Hans-Jürgen. 1992. Language decay and contact-induced change: similarities and differences. In: Matthias Brenzinger (ed.), Language Death. Factual and Theoretical Explorations with Special Reference to East Africa, Berlin-New York: Mouton de Gruyter. 5980.

Scherrer, Joann Carole. 1978. Fisher folk of the desert: an ethnography of Elmolo of Kenya. Charlottesville, VA: University of Virginia Ph.D. dissertation.

Spencer, Paul. 1973. Nomads in alliance. London: Oxford University Press.

Stiles, Daniel. 1988. Historical interrelationships of the Boni with pastoral peoples of Somalia and Kenya. Kenya Past and Present 20. 38-45.

Tosco, Mauro. 2001. The Dhaasanac Language. Köln: Rüdiger Köppe.

Tosco, Mauro. 2007. Something went wrong: On the historical reconstruction of the Dhaasanac verb. In: Rainer Voigt (ed.), "From Beyond the Mediterranean”. Akten des 7. internationalen Semitohamitistenkongresses (VII. ISHaK), Berlin 13. bis 15. September 2004. Aachen: Shaker. 265-280.

Tosco, Mauro. 2012. What terminal speakers can do to their language: the Case of Elmolo. In: Federico Corriente, Gregorio del Olmo Lete, Ángeles Vicente and Juan-Pablo Vita (eds.), Dialectology of the Semitic Languages. Proceedings of the IV Meeting on Comparative Semitics, Zaragoza 6/9-11/2010 (“Aula Orientalis - Supplementa 27”). Sabadell (Barcelona): Editorial AUSA. 131-143. 


\section{Appendix: A list of remembered Elmolo words}

This lexicon contains all and only the material collected during 2010 and 2012 fieldwork. Material documented in Omondi (2008), Omondi and Otieno (2008), or Lengosira and Lenapir (2010) and accepted by our informants is preceded by $\bullet$. For data found in more than one of the above only Omondi and Otieno (2010), which is the most complete source, is cited. Previously undocumented material is preceded by $\mathcal{O}$. In the other cases reference is made to the earliest publication (but Heine 1980 is preferred to the early data in Heine 1972/73). A few items whose meaning was highly disputed among the informants have been discarded, although alternative meanings have been retained for a very few items.

Samburu material in the accompanying sentences is written in bold; transcription and tone marking is tentative. The transcription is phonological; the following conventions and abbreviations are used:

$$
\begin{aligned}
& <\mathrm{c}>=/ \mathrm{g} / \\
& <\mathrm{j}>=/ \mathrm{d} / \\
& <\breve{\mathrm{s}}>=/ \mathrm{d} / \\
& <\mathrm{y}>=/ \mathrm{j} /
\end{aligned}
$$

IMP: Imperative

PL: Plural

SG: Singular

VEN: Ventive

- aak - a command or request to come (Omondi and Otieno 2008: 3)

aam - eat! (also: yaam); Heine (1980: 203) aam; maape num aam-a 'let's go and eat food!'

○ aap - shade of the shelter; towanna ta-aap 'sit in the shade!;' maape aap 'let's go into the shade'

aar - male crocodile; Heine (1980 203) áar, PL árré 'bull, ox;' k-a-tama aar gita lai 'the crocodile has broken my net;'

- adum - sp. of shrub (Omondi and Otieno 2008: 3)

afur - four; Heine (1980: 203) áfur

- agapa — to pull (Omondi and Otieno 2008: 3; also: agaba)

- agote - mother (Lengosira and Lenapir 2010: 1); but cf. Heine (1980: 206) ínkota

- ailila - to fish standing on the raft and using a harpoon (Omondi and Otieno 2008: 3); $\boldsymbol{k}$-ailila

'I am fishing with the harpoon;' kai como aililaa 'I went fishing...;' ke-como cililaa

'he/they went fishing...'

○ ajia - to fish at moonlight (cf. also waram); $\boldsymbol{k a}$ ajiá ta-l-kadiš 'I am going to fish at night from

the raft'

- akapa - young paternal uncle (Omondi and Otieno 2008: 3)

- alak - twirling wind; (Lengosira and Lenapir 2010: 1 'wind in general')

○ alalac — wind (general term); (Heine 1980: 204) árrac

O alapate - fin opposed to the luk, in dorsal position, close to the tail 
- aliano - wedding necklace (Omondi and Otieno 2008: 3); made by men and tied around a woman's (bride's) neck by the husband during marriage as a sign of sealing of the marriage; upon childbirth, the father takes it off the mother and puts around a baby boy's neck; the mother herself does it for a baby girl; v. also gasar

- álite - spoon made from the jaw of a Nile perch (iji, ijinte), esp. used to feed a baby; v. also kool

ammúi - hand; Heine (1982: 31) ámui, PL ámui 'wrist'

- anafe - to float (Omondi and Otieno 2008: 3 have ajafe); $\boldsymbol{k}$-a-anafe 'I am floating' anayey — I am fine ('I came;' answer to anatey); Heine (1980: 203) ánáy-ey

- anapale — boy, male child

- anatale - girl, female child anatey — how are you? ('did you come?'); Heine (1980: 203) aná-tey

- anderi - Loiyangalani

- angay - rope used on the harpoon for crocodile hunting and for tying logs together in making the raft (Lengosira and Lenapir 2010: 3)

anka - elder brother; elder brother's son; Heine (1982: 31) ánka 'my brother'; also: angaane.

- anto - brother's daughter (Omondi and Otieno 2008: 3)

aste - sun; Heine (1980: 204) áote

- apap - Nile perch belly (v. tam)

- apıótc - sp. of small bird with feathers upon the head

- apryóle - long neck cormorant

apooda - good; Heine (1980: 204) ápó-da

- arangalate — butterfly

arap - elephant; Heine (1980: 204) árap

- arapile - leader of the elders' council (Omondi and Otieno 2008: 3)

- arav - afternoon

- ardey — to talk; Heine (1980: 204) ár-dêy (VEN-speak\IMP.SG), ár-déy-a (IMP.PL)

- ardopa - to mix water and clay to make mud for the shelter; angaane y-ardopa barbár 'brother, mix the soil;' containing Heine's (1980) VEN prefix ár-

- argabite - acacia (Acacia tortilis), or doum palm (Hyphaene thebaica) (uncertain meaning)

- argapa - to pull out (Lengosira and Lenapir 2010: 3); $\boldsymbol{k}$-ay argapa l-gita 'I have pulled the net out;' containing Heine's (1980: 197) VEN prefix ár-

- argar - cheek (Omondi and Otieno 2008: 3; hippopotamus' cheek)

arkai — crow; Heine (1980: 205) hárgac, hárgaine

- armarita - to round up the ends of the net while fishing (Lengosira and Lenapir 2010: 3); containing Heine's (1980: 197) VEN prefix ár-

- arraminto - necklace of beads given to men as a first present when they have killed a hippo

- arrosa - v. rros

ar(si) — to give; pice arsi 'give water!;' waga si 'give (us), God!'; Heine (1980: 209) síise and the VEN prefix ár-

- artallite - hermaphrodite tilapia

arte - barbers (Barbus bynni bynni or occidentalis); Heine (1982: 27) árte, PL ártên

- artunda - to swim on the surface; to float; la-morran e-artunda l-kinyay 'hey you warriors, the crocodile is floating;' ke-artunda soto lay 'my friend is swimming;' containing Heine's (1980: 197) VEN prefix ár- 
arwate - girl (before circumcision); Heine (1980: 205) háruw'á-te

arwe - to call; Heine (1980: 210) wê with the VEN prefix ár-

○ aulite - wind when twisting

- aw - maternal uncle and maternal uncle's son (Omondi and Otieno 2008: 4)

- aw metc - eldest maternal uncle (Omondi and Otieno 2008: 4)

- aw nina - youngest maternal uncle (Omondi and Otieno 2008: 4)

awarac - hyena; Heine (1980: 210) wárac

- awate - a kull (v.) pot used by women to drink during menstruation

ayya - where?; Heine (1980: 204) áyya 'where is?'

- bokste - shell of tortoise, also used as a plate (possibly a Samburu word; Lengosira and Lenapir 2010: 2); Heine (1980: 208) ógopte 'turtle shell'

- bovt - thigh of hippopotamus (Omondi and Otieno 2008: 4)

bovtc - fish trap (kind of a bell made with doum palm used to trap fish in night time); Heine

(1980: 204) búúte (PL búúténo is Samburu)

caadde - star whose appearance marks the beginning of the crocodile's breeding season

caar - leopard; Heine (1980: 204) cáar

- cak - to chew (Lengosira and Lenapir 2010: 2)

- cal - clay (dry; used to decorate a hippo killer) (Omondi and Otieno 2008: 4)

- carrate/šarrate - thigh

- cecr - dust from doum palm leaves (Lengosira and Lenapir 2010: 2)

- crir - area under the testicles (both humans and hippo) (Omondi and Otieno 2008: 4; specific

for hippos)

- cosr - lake shore

- cuu - enemy (Omondi and Otieno 2008: 4)

- cuba - external red part of the gills (v. laka)

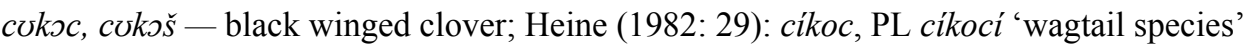

- dangs - point behind the knee (Omondi and Otieno 2008: 5)

- date - trough; cultural: the trough used in the gaante of the Marle (Ori Alpula) clan in order to hold the saarad (bag containing the clay)

- daw, PL - $n$ - covering of the gills of the Nile perch

- dayesilo abarie - good evening (answer)

- déc - fresh fish soup (Omondi and Otieno 2008: 5)

decc - a sp. of seasonal fish; Heine (1982: 23): decc, PL decci Heterotis niloticus

- décn - thin strip of animal skin tied to a baby's waist (Omondi and Otieno 2008: 5); which sp.

of animal (e.g., mudfish) depends on the clan: Ori Alpula use goatskin

- décr - internal bark of acacia, soaked and used against limb diseases

demelec - orphan infant hippopotamus; Heine (1982: 28): demelec, PL demeleci

O dies - 1. fisher (collective name of five Elmolo clans: Ori Gaya, Ori Sayo, Ori Sooolle, Ori

Gaalgite); 2. Dhaasanac; cf. Dhaasanac dies 'poor; fisherman' (Tosco 2001: 494)

diik — blood; Heine (1980: 204) diik

O dit - to be possible (Heine 1980: 204 has dît 'to kick, step on')

- dikat - shrub of the dortc type (Lengosira and Lenapir 2010: 2) 
- dim, PL -in - gnat

- dims - beads (Omondi and Otieno 2008: 5)

- dirI - big cooking pot

- dodoto - grass with roots (Omondi and Otieno 2008: 5)

- domstc - medium size spear (Omondi and Otieno 2008: 5)

duur - to sing; Heine (1980: 204) dûr

- dvdvma - doum palm string worn as a head gear by women of the Ori Kaara and Ori Gaalgite clans after circumcision (Omondi and Otieno 2008: 5)

- dvkvr - navel of hippo (Omondi and Otieno 2008: 5)

- dorte - sp. of tree (Omondi and Otieno 2008: 5: shrubs)

- doops - heavy water silt; dirt in water (Lengosira and Lenapir 2010: 2)

- egartite - a small kind of black Nile perch

- ekan - sharpening stone

- eketu paate - good afternoon; answer: oni marige

- elato - wood that insects feed on (Lengosira and Lenapir 2010: 3)

elete - jackal; Heine (1980: 205) éle-te

- elit - early night, around 8 or 9 p.m. (Omondi and Otieno 2008: 5)

elme - sheep; Heine (1980: 205) élem

engere - part of the gill of the tilapia closer to the fish body; Heine (1982: 25): ćnkere, PL

$\varepsilon n k \varepsilon r a n i$, erroneously as 'tongue of tilapia'

enu — milk; Heine (1980: 205) énu (also 'udder, breast')

- enuto - reeds used in thatching the house, when still in water (corresponding to Samburu masaI) (Lengosira and Lenapir 2010: 3)

- enalate - Golden Nile perch (Lates niloticus) (Omondi and Otieno 2008: 6)

- erduk, PL - $i$ - fore limbs of the hippo (Omondi and Otieno 2008: 5); erduk iniyama 'he ate erduk'

- ergit - round stone (often used for grinding, used together with geet) (Lengosira and Lenapir 2010: 3)

○ erle - sp. of mudfish

errep - tongue; Heine (1980: 205) érrep

○ esi-grandfather

ewe - white; Heine (1980: 206) éwé

○ $\varepsilon d v k$ - bad milk

- $\varepsilon \varepsilon l$ - grave; heap of stones (Lengosira and Lenapir 2010: 3 )

efına - pelvic fin of tilapia; Heine (1982: 25): héfına

- cjin - early dawn, around 4 a.m. (Lengosira and Lenapir 2010: 2)

○ $\varepsilon l \varepsilon-$ up

- $\varepsilon m m \varepsilon r$ - lines in the palm (Omondi and Otieno 2008: 6)

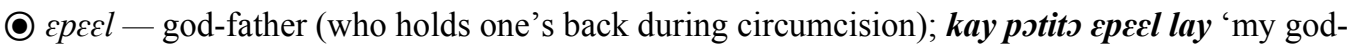

father is calling me;' cf. Gawwada peel-h-o, peel-t-e 'friend' (unpublished data)

- $c r d s$ - fat from the fish soup (v. crr) (Omondi and Otieno 2008: 6)

- $\varepsilon r r$ - dry fish soup, also used as laxative and given to women after childbirth (Omondi and

Otieno 2008: 6)

- $\operatorname{ctct\varepsilon ~-~tortoise~(Omondi~and~Otieno~2008:~6)~}$ 
cyats - mat used for cleaning fish

farrit - finger, toe; Heine (1980: 205) fârr, Singulative fárr-it

O fayy - it is fine, good, OK (widely attested in Cushitic/Omotic)

fiir - mat; covering; cloth; Heine (1980: 205) firr, firr-ne

- firic - stirring stick (Omondi and Otieno 2008: 6)

- frrians - mat on which fish is placed when scales are removed (Omondi and Otieno 2008: 6) foc - eight; Heine (1980: 206) fúe

- gaa - the two side logs of the raft (Omondi and Otieno 2008: 7) gaalte - camel; Heine (1980: 205) gál-te, PL gáal

- gaante - shrine (Omondi and Otieno 2008: 7); one for each clan, except the Ori Gaya, located on Loryaan island. The first gaante coming from the North belongs to the Marle clan, then, moving southward, the Ori Soolle, Ori Kaara, Ori Gaalgite gaante are found.

- gaat - waterway (between islands or island and mainland) (Omondi and Otieno 2008: 7) gala - sp. of barbers (Distichodus niloticus or rostratus); Heine (1982: 23): gálla, PL gallân

- galmate - spear stick to which an iron tip can be added

- galto - cave (Lengosira and Lenapir 2010: 3)

- gara - traditional stool made of palm tree trunk (Omondi and Otieno 2008: 7)

- gargarte, PL -ni - ornament made of an ostrich egg, worn on neck by women

- garipit, garipite - rock surfacing in shallow water (Omondi and Otieno 2008: 7); $\boldsymbol{k}$-adaca garipite 'I stepped on the rock'

O gasar - necklace of animal skin which a father makes and the mother's brother blesses and puts on an infant's neck until breastfeeding finishes, together with the aliano which the father removes from the mother's neck. The aliano goes back to the mother after weaning, while the gasar is thrown into the water

○ geel - vagina; cf. Arbore gél (Hayward 1984: 446)

- gecla - part of the tortoise back with soft skin

- gecr - heron (Omondi and Otieno 2008: 7) gecr - male (human); Heine (1980: 205) géér, PL gúra 'husband, old man' geere - stomach of crocodiles/humans; Heine (1980: 205) gére

- geet - flat and round pebble (Omondi and Otieno 2008: 7)

- gecya - a variety of egret

- gecya gorgor - a small variety of egret

genc - buffalo

- gerei - reed-like plant (shrub) used for making mats (Samburu lkerei)

○ giila - skin around the turtle shell

gin - back; tail of fish; kati gin enjore 'I am the last in the group;' kcti gin enjore 'he is the last in the group,' iti gin enjore 'you are the last in the group'; cf. also Heine (1982: 27): ginct, PL gincti 'back half (of kingfish)' and Lengosira and Lenapir (2010: 4) ginne 'human waist'

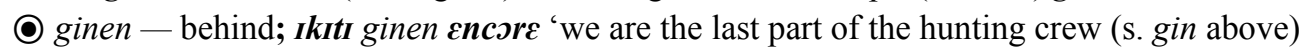

○ girya taka — somebody without a limb

- gitar - 1. bad smell; mitıkar gitar 'do not throw upon (me your) bad smell!;' 2. water silt

pushed by waves from the lake (Omondi and Otieno 2008: 7)

- gIIr - penis (Omondi and Otieno 2008: 7) 
gIIrIgere - area under the penis; $\boldsymbol{k}$-arem gIIrIgere 'I'll put a finger in your ass;' Heine (1982: 28): girgecre, PL girgecreni 'loin of crocodile'

gIma - heel; Heine (1980: 205) gíma

gImate - tick; Heine (1980: 205) gíma-te

- gInct - lower part of fish (when cut halfway) (s. gin above)

gooba - male doum palm

- goorot - side of the shelter where fire is kept and women sit

gon - body; Heine (1980: 205) gôn

O gosl - cursing of the enemy, made with burning the masaI grass

gosr — path; Heine (1980: 205) gôr, PL górtóno

- goora - he-goat (Omondi and Otieno 2008: 7)

gəos, PL - $i$ - 1. throat; 2. Nile perch tongue; Heine (1980: 205) gôs 'chin;' k-at-ama gəos 'I have eaten the Nile perch's tongue;' 3. passageway between island and land when water retreats gore - heifer, young female hippo which has not given birth; Heine (1982: 28) góre

- grreys - North-West to South-East wind (Omondi and Otieno 2008: 7 have goreiro)

- gufanto - cup for babies

gum - knee; Heine (1980: 205) gûm; $\boldsymbol{k}$-aaya gúm 'my knee is hurting'

gura - people; Heine (1980: 205) gúra PL of géér 'husband, old man'

guris - mature male hippo; Heine (1980: 205) gúris

- gusayo - raft made of four logs and traditionally used as a bride price (Omondi and Otieno 2008: 8)

- gofayngats - cap of men (Lengosira and Lenapir 2010: 4)

$g v f \varepsilon$ - Nile perch stomach; Heine (1982: 25) guf, PL gùfin 'fat in protruding part of belly of

Tipalia'

golmays - sleeping mat for babies; Heine (1982: 30) gólmayo, PL golmayoní

gomatc - turtle; Heine (1980: 205) gúmaa-te

- govlac - back; end of backbone in humans; tail, end part of the back of crocodile (Omondi and

Otieno 2008: 7)

○ govs - anus (cf. Somali gus 'penis')

gouta - big

- govtc - eldest paternal uncle (Omondi and Otieno 2008: 8); hooked spear which cannot be removed from a hippo

- govts $\varepsilon r \varepsilon$ - senior warriors

- gyct - male tilapia (the male of kora)

haal - mature female crocodile; Heine (1980: 205) háal

- haan - udder (Omondi and Otieno 2008: 8)

hakaIte - herbal, traditional medicine; Heine (1980: 205) hékai-te; $\boldsymbol{k a - y e w ~ h a k a i t e ~ ' I ~ w a n t / n e e d ~}$ hakaite'

- havtats - black sparrowing goose

- hayye - good night (answer) (Omondi 2008: 30: ayie)

- here - name given to the Elmolo by the Dhaasanac

heck, $\varepsilon \varepsilon k$ - fire; Heine (1980: 204) éek

- hecl - soft soil

hecm — bladder of Nile perch; Heine (1982: 32) hécm 
hect — sand, soft soil; Heine Heine (1980: 205) héed

- highig - root of Salvadora Persica given to women as a laxative after child delivery horıa - club; Heine (1980: 207) kóriat

- hok, PL hokni — arm, arms (Omondi and Otieno 2008: 8)

- hovrat - zebra skin kept in the shrine of the Ori Kaara clan and used for blessings in prayers for good luck during hippo hunting (Omondi and Otieno 2008: 8)

iif — to sleep; Heine (1980: 206) iif

iik - to drink; Heine (1980: 212) ik

iji - Nile perch (Lates niloticus); Heine (1980: 206) iji

ijinte - young Nile perch; Heine (1980: 206) íjin-te

○ iko - light silt

il, PL inna - eye; Heine (1980: 206) il, PL ínna

ile - stone; Heine (1980: 205) êl, éll-e

ilete - young girl before puberty; cf. Heine (1980: 205) héle 'children'

○ ilik - joint bone, generally put on top of sticks and used as a weapon

ilko - tooth; Heine (1980: 206) ilik, PL ilk-o

- ill - part of the net (Lengosira and Lenapir 2010: 5)

O illante - gulf

- imat - rope woven at one end of a net to indicate its front part (Lengosira and Lenapir 2010: 5)

- ingannate - cooking pot

- ingo, ingoye - maternal aunt (Omondi and Otieno 2008: 9)

inite, PL inno - egg; Heine (1980: 206) ini-te, PL ínno

- ir - soft green grass (Lengosira and Lenapir 2010: 5)

irri — rain; Heine (1980: 206) íri

O iwate - black

Ikana, PL -ni - belly part of tilapia; Heine (1982: 25): íkana, PL ıkananí

- Ilarla - a sp. of swamp bird (Lengosira and Lenapir 2010: 5)

○ Ina - umbilical cord of fish

Inofa - saliva; Heine (1980: 205) ényufa

- Irra - cliff

Irraac - sp. of reed found in shallow water

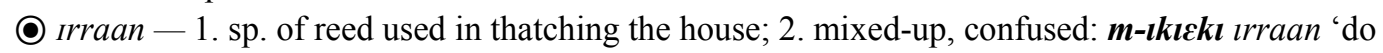
not give me your mess!'

jeyn — palm of hand; Heine (1980: 205) géne 'palm, sole'

- jiike - South/South-West to North/North-East wind (Omondi and Otieno 2008: 9)

jIIr - elbow; Heine (1980: 210) has yirr

- jurrante - horn of cow, specifically the one kept in the gaante of the Ori Gaalgite clan

- joma; arjoma - to crawl in water, with hands and feet touching the bottom: $\boldsymbol{k}$-a-joma 'I crawl in the water;' i-juma 'crawl in the water!;' a-jume 'I crawled,' $k \boldsymbol{\varepsilon}$-jome 'he crawled;' with ar- (VEN): to walk in the water (also of crocodiles in shallow water): $k$ a-arjoma 'I am

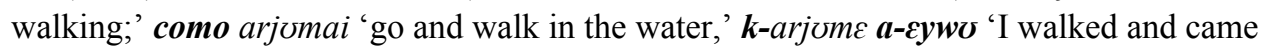
back' 
kaal — meat around the crocodile's kidney; Heine (1980: 206) kâl 'kidney'

- kaale - sternum, collarbone (uncertain meaning) (Omondi and Otieno 2008: 10: kale 'chest') kaans - rope made of palm tree leaves/fibers; Heine (1982: 28): kaányo, PL kaanyoni 'rope of fish harpoon'

- kaar - belt used to tie the sila

kaara — kingfish (Labeo horie); Heine (1980: 206) káára

- kaaso - front tooth of hippo; ka=tone turuka kaaso 'the hippo bit me with its front teeth'

- kaaye urru - name of a wind (Lengosira and Lenapir 2010: 6)

kac - chest; upper part of fish (when cut halfway); Heine (1980: 206) kac

- kadifa, PL -ni-metal (Omondi and Otieno 2008: 9: kadifane)

kadiš - raft; Heine (1980: 204) has árte, PL árgi; Heine (1982: 21) reports it as Samburu: SG

lkádic, PL lkadicí, but cf. also Dhaasanac kadic (Tosco 2001: 509); Camus lkádic, PL lkádíci (Heine 1982: 16)

kalate, PL - $n i$ - ear pendant made of a cow rib usually worn by women after marriage and as an earring by men who killed hippos; also used to give babies water; Heine (1982: 30): kaláte, PL kalateni

- kalays, PL -ni - testicle (Omondi and Otieno 2008: 10); e-kitigina nkjeya kalayəni 'may the disease destroy your testicles!'

- kalı - sharp, knife-shaped stone traditionally used for cutting (Omondi and Otieno 2008: 10)

- kapite - piece of trunk of doum palm used as a roller to drive a raft into the water from the shore (Omondi and Otieno 2008: 10)

- karamet - assistants of the arapile

- karamu — basket made of doum palm (Lengosira and Lenapir 2010: 6)

karato - a sp. of black biting fly; cf. Heine (1980: 206) kárran 'tsetse fly'

○ karav - sp. of shrub

○ kargit - human faeces

kari - back of crocodile; Heine (1982: 27): kári; $\boldsymbol{k}$-atama kari 'I/he hit the back'

karis, karsis — cook; Heine (1980: 206) káris 'to cook, fry, boil'

- karit - West to East wind, not as strong as kuyur (Omondi and Otieno 2008: 10)

- karkar - pebbles

- karkarato, PL -ni - belt made of hide upon which ostrich eggs are sewn and used at the first monthly period of Ori Alpula, Ori Kaara, and Ori Gaalgite women

- karmet - ceremonial food used e.g. at mourning ceremonies of chiefs

- karmit - net used for cooking fish (which is put inside)

- karns - a sp. of big barber fish, bigger than arte; k-aibuya karno 'I caught karno'

karris - molar tooth; Heine (1980: 206) karris 'cheek; molar'

○ kaytz - tortoise's egg nest

○ keše gorgor - cursing of the marabou, done with fire

$k \varepsilon d I s$ - housefly; Heine (1980: 206) kédit

○ kecpopsrta - fish which can be seen in water

$k \varepsilon n$ - five; Heine (1980: 206, 204) kên, cên

kencte - mosquito; small white biting fly; Heine (1980: 206) kénéte

$k \varepsilon r$ - dog; Heine (1980: 207) kêr

kidime, PL kidmeni - cooking stone; PL (three in the house); Heine (1982: 30): kidime, PL 
- kikima - skeleton of the trkır catfish (used as a trap against enemies)

- kilpayte - sp. of shrub, whose root (urrac) is used in medicine

○ kimminte - wrist

kirit - fishing net; Heine (1980: 207) kirit 'piece of fish net'

kıdo - brownish, long-tailed tilapia (Tilapia zillii); Heine (1982: 22): kído, PL kídôn

kIllas - type of clover; Heine (1982: 29): kılaáo, PL kılaaoni 'seagull, big species'

- kımbay - depression filled with water

- kIrmayts - porcupine

kısa - night; Heine (1980: 207) kisa 'darkness'

- kIsa kurr - midnight

kool - 1. shoulder; 2. wing of bird; 3. Nile perch jaw; 4. spoon made with 3.; Heine (1980: 207)

kóol 'spoon'

koon — to bring; Heine (1980: 207)

koriis - tigerfish (Hydrocynus vittatus or forskahlii); Heine (1980: 207) kóris

kormit - hook; Heine (1980: 207) kórmit 'fishhook;' k-eimiyani kormit 'the hook is not sharp;'

k-epi kormit 'the hook is sharp'

$k o l$ - to laugh; Heine (1980: 207) kól

- ksnakate - type of barbers

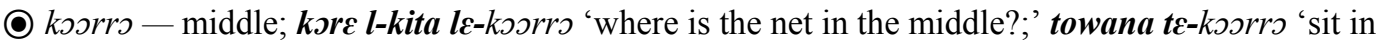

the middle;' keti ksorrs enjore 'he is in the middle of the group,' ititi kosrrs enjore 'you

(PL) were in the middle of the group;' ikitita ksorro enjore 'they are in the middle of the

group;' yo sti ksorro enjore 'we were in the middle of the group;' yo sti ta ksorro enjore

'we are in the middle of the group'

- ksyy - 1. midnight star, usually appears from the South in April and marks the season of heavy

breeding of water birds, fish and hippos, 2. internal fats of hippo, e.g. fat in stomach; 3.

crocodile's nest (Omondi and Otieno 2008: 10)

kspat - locust; Heine (1980: 207) kópat

$k \supset p \varepsilon$ - sandals made from hippo's hide; Heine (1980: 207) kôp

○ kspitc - to sit; kopinite 'sit down!;' k-i-kopite 'he sat down' (no longer actively used, replaced

by a Samburu verb)

- $k o r$ - fish eagle (Omondi and Otieno 2008: 11)

kora - female tilapia; Heine (1980: 207) kóra

- korcIr - one of the two moieties (cf. marsala)

ksrr - Samburu; Heine (1980: 207) korro

kstajs - cormorant; Heine (1982: 29): kotáyo, PL kotayoni 'heron species (black, white throat)'

- kulal - temporary round shelter made of stone wall, usually made at night by fishermen when

fishing (Omondi and Otieno 2008: 11)

- kulale - penis of mudfish (Lengosira and Lenapir 2010: 6, as 'penis')

- kulic - midday (Omondi and Otieno 2008: 11)

- kummayo - short knife used during women's circumcision

kunnate - small pot; Heine (1982: 30):

kunuf, PL kunufo - nail; peer group; Heine (1980: 207, 213) kúnuf, PL kúnúfó 'fingernail'

- kute - green grass stem when dead and hence turned brown (Omondi and Otieno 2008: 11)

kuul - cup-like pot used for cooling and drinking water and drinking soup; Heine (1980: 207) kûl

'water-pot' 
- kuyur - stormy wind from West to East (Omondi and Otieno 2008: 11)

kuyyu, PL kuyye - star; Heine (1980: 206, 217) húyu-te, PL húyuk

- kvkvtı — necklace made from ostrich eggs (Omondi and Otieno 2008: 11)

- komoys, -ni - short, blunt spear used by boys for practicing (Lengosira and Lenapir 2010: 6);

mintorrá kumuyo áy 'do not lose my k.!;' k-ay-tooraye kumuyo 'I lost the kumuyo'

konats, PL -ni - rat; katama kunato benc lay 'the rat has torn my bag;' Heine (1980: 207) kúnáto

- kordan — to paddle; $\boldsymbol{k}$-a-kurdan 'I am paddling'

- korla - hunting party

- kotryame - black-headed ibis (Omondi and Otieno 2008: 11)

laf - bone; Heine (1980: 207) laf

- laji - moiety (Samburu 'age-set') (Omondi and Otieno 2008: 12)

laka - area around the gills (v. cuba); Heine (1980: 207) láka 'tonsil'

lama - two; Heine (1980: 207) lááma

- lap - calm atmosphere (Omondi and Otieno 2008: 12)

- leante - foam

lec - moon; Heine (1980: 207) léhe

lep — fish hole; Heine (1982: 29): lep, PL lépîn 'hole in the lake ground where fish hide'

- lieente - school of fish

liis — catfish (Bagrus docmak); Heine (1980: 207) liis 'mudfish'

lorrian - island; specifically: the island in front of Layieni village; Heine (1982: 31): lorriân, PL lorriâni

- losurlac - sp. of tree whose leaves are pounded and mixed with hot water against chest problems (possibly Samburu?)

luk — leg, foot, ventral fin; Heine (1980: 207) lûk

O maar - calf

- magosa - to pull (Omondi and Otieno 2008: 12)

maka - sweet; Heine (1980: 207) máka

- makste - drought

- maku - rope used for carrying fish (Lengosira and Lenapir 2010: 7)

- malac - Milky Way

- malinte - waistband made of doum palm (Omondi and Otieno 2008: 12)

mantano - twins; Heine (1980: 207) mántáno

- mara kstays - spotted, small cormorant

- margar - the area where nets are joined together

- marisa - collarbone (Omondi and Otieno 2008: 12)

- marit - stick for wrapping the fishing net (Lengosira and Lenapir 2010: 7: 'a wooden shuttle')

- marsala - one of the two moieties (cf. korcrr)

- masa - thatching grass from the lake; shrub growing in water (Omondi and Otieno 2008: 12)

- masaka - to arrange, put together; masaka l-kitani 'arrange the nets!'

may - come!; Heine (1980: 190) má-ac (IMP.SG)

mbala - fish scales; Heine (1982: 23): mpálái, PL mpála from Samburu for 'snake skin, paper'

mete - head; Heine (1980: 207) méte

- mecre - intestines 
- $m \varepsilon m \varepsilon$ - what? (Omondi and Otieno 2008: 12)

- $m \varepsilon r l \varepsilon-$ scar (as a result of burning for healing)

- metcgIr - first in the group; yo oti metcgIr enjore 'we are the first in the group;' ikiti metcgIr enjore 'we were....;' kati/ati metcgIr enjore 'I was/am....;' keti mitigir enjore 'he was...;' iti metcgir enjore 'you are...'

- migite - vein

miiddi - harpoon for training children in fish hunting; Heine (1980: 207) mídi 'needle'

- miin - face, forehead (Omondi and Otieno 2008: 13)

○ miinte - earring

O miit - belongings of a deceased person, assembled and later distributed

( mirr - depression in the soil

mit — buffalo; Heine (1980: 207) méet

○ millika - ghost

min - house; Heine (1980: 207) mîn, PL mine 'houses, village'

- mosia - sex partner (?); see below

- mosiaako - your girlfriend

motolac — ankle; Heine (1980: 207) mótolac

moere - warrior; Heine (1980: 218) mó erre

mostya - a sp. of small white fish-eating bird with yellow beak; Heine (1982: 29): mooitea, PL

mooiteani 'white heron'

- mote - metal blade used with the harpoon for hunting hippos and crocodiles (Lengosira and

Lenapir 2010: 7)

( motspira - a sp. of very small cormorant

- mpvrdede - loose human faeces

○ mugó - to dive; mugó 'dive!;' míi-mug 'do not dive!; e-mugo l-kinayin ta-mpaso 'do not dive, there are crocodiles in the lake'

mutar, PL -ri - a sp. of catfish (Auchenoglanis occidentalis); k-aybuya mutarri tomon 'I caught ten catfish;' Heine (1980: 208) mútar, PL mútar-ne

○ morr — donkey's faeces (from Samburu?)

- moto, PL - $n$ - firewood

(O) molle, PL -ni - leg bracelet

( movr - round; ni-kingero mor nabs 'we made a round with the net'

- naaps - belly (Omondi and Otieno 2008: 13: 'naval [sic!] of hippopotamus')

- naas - breast, chest (Omondi and Otieno 2008: 13: 'chest of hippopotamus')

- nakıdods - frog (Omondi and Otieno 2008: 13); ke-tobwa nakıdっds 'the frog is uttering its sound'

- nakvlso - flesh around the face, covering from the ears to the area around the eyes of a hippo

(Omondi and Otieno 2008: 13: nakulsoni-possibly a PL)

- nallepa - baby boy

napala - ostrich; Heine (1980: 208) nápal

- napslmstys - kind of small aquatic bird (water tick)

- natale - today; Heine (1980: 204) ántale

- natedeeye - girl who has given birth out of wedlock, before marriage (Omondi and Otieno 2008: 13) 
- nepe - rope made of pounded leaves of doum palm, used to mend the nets (Lengosira and

Lenapir 2010: 7: 'palm tree leaves')

nєpe - ear; Heine (1980: 208) nêp, PL nép-e

niik - lion; Heine (1980: 208) néek

○ nkumuyo - knife used in women's circumcision

- ntikitiki - car; motor vehicle in general (an Elmolo neologism)

nukate - young or female mudfish; Heine (1982: 27): nvkáte, PL nvkatení

- nunac - penis of fish

nuит — food; Heine (1980: 208) núum

- nuun - antelope horn where the harpoon is inserted (the horn is inserted in the stick)

nonoma - fish egg; gata kara nunuma 'the fish has eggs;' Heine (1982: 23): núnuma, PL nunumani

novtc — lamb; Heine (1980: 208) núú-te, PL núuk

- yaaric - Dhaasanac (Omondi and Otieno 2008: 13); cf. Dhaasanac yaaric, the name of a tribal section (Tosco 2001: 523)

- yamelsk - silver tilapia, with red patches around gills (Omondi and Otieno 2008: 13)

- yunnate - cooking pot (Omondi and Otieno 2008: 13)

- yolyolla - sp. of biting water spider

- nakirrim - hippo-hunting practised by young people

- narda - tip of the crocodile tail

naud - crocodile; Heine (1980: 208) náut

naute - young crocodile; Heine (1980: 208) jáú-te

ncعlle - a sp. of small tigerfish (Alestes baremose); Heine (1982: 22): ncéle, PL neelení

- oni marige - good morning (reply to waaka parite); morning greeting (Omondi 2008: 30: ini margi)

ook — throat; Heine (1980: 208) óok

- orro - wood (Lengosira and Lenapir 2010: 8); piece of wood used to support the regalia in the shrine of the Ori Kaara clan

smolI - throat of fish, covering the gills

sməd - young mature male crocodile; Heine (1982: 27): ómod, PL ómodí 'extremely old crocodile'

- sna - Adam's apple (Omondi and Otieno 2008: 14: 'throat of hippopotamus')

sol-donkey; Heine (1980: 208) óhol

so - mouth; language; Heine (1980: 208) óho, PL óh-ono; óó 'language'

- solan - lie (n.) (Omondi and Otieno 2008: 14)

- sonate - fruit (Omondi and Otieno 2008: 14)

- sonsr - trunk of hippo

- orI - clan

- ori alpula - different name of the Marle clan

- orr kaara - 1. Ori Kaara clan (Omondi and Otieno 2008: 14), known for hippo hunting alongside fishing; 2. their shrine, used to pray for blessing in hippo hunting

- sria - back of the head (Omondi and Otieno 2008: 14) 
st - to dig; cf. Heine (1980: 208) ot

- staka - one hundred (Omondi and Otieno 2008: 14)

ote - cow; Heine (1980: 208) óte

○ गyecre - common ibis

- paare - tomorrow (Omondi and Otieno 2008: 15)

- palak - pieces of broken pot (Omondi and Otieno 2008: 15)

- palcte - young boy before puberty

O palpal — the front and lower part of the sila; cf. palpale and Heine (1982: 30): sila le apálpalle 'front apron,' lit. "apron of female private parts"

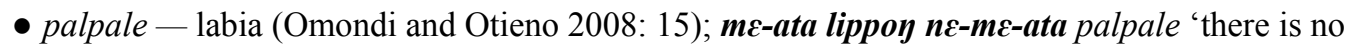
female without labia;' borrowed from Rendille or from Samburu?

palpalis — toad; Heine (1980: 208) pálpalis 'frog'

par — back part of fish; Heine (1982: 25): páàrr, PL páàrrí 'body excluding belly parts (of

Tipalia)'

- parac — mid morning

- parkan - North to South dusty wind (Omondi and Otieno 2008: 15)

○ parkede - afternoon

parparr - soft meat from the ribs of crocodile/hippo;' Heine (1982: 27) párparr, PL párparrí 'rib of crocodile;' parparr ini=yama 'he ate parparr'

O parri-day

pau - lake; Heine (1980: 208) páu

paua - heart; Heine (1980: 208) páúa

O pedo - clay found in shallow water

O peerre - name of an insect (white ant?) that penetrates deeply into the raft

O peranto - stick for drilling fire

pecs - tail of crocodile; Heine (1982: 28): pécs

- pelemae - come!; used as an answer to a calling (Omondi and Otieno 2008: 15)

pcyte - fish; Heine (1980: 208) péi-te

pice - water; Heine (1980: 218) pice; waak pice na=si 'God gave us water'

pirik — to lighten; waak ini=pirik-e 'God sent lightning'

O pirik - sp. of water reed where fish eat

- pirika - lightning

- piye elle South (Lengosira and Lenapir 2010: 9); cf. Heine (1980: 208) pii 'land, ground; below'

- piye urru - North (Lengosira and Lenapir 2010: 9); cf. Dhaasanac Púrru 'sky, high', dáá

("side") ?úrru - 'South' (Tosco 2001: 485)?

O pirlac — a small kind of yergo (small yellow tilapia)

- pokolac - young male bull (Omondi and Otieno 2008: 15)

- pool - shallow water where fish eat

- poolo - thin, scattered clouds (Omondi and Otieno 2008: 15)

poor - 1. red; Heine (1980: 208) púrra; 2. name of a mountain west of Palo; ini=poor-ide 'it is red'

- porsia - different name of the Marle clan

pəoy - to cry; Heine (1980: 208) pooy 
pэor - cursing of crocodiles (using feathers of the Scared Ibis and donkey's dung, thrown into the water)

porte — harpoon for hunting crocodiles; Heine (1982: 28): porte, PL pəorteni

porat - bee; Heine (1980: 208) póruat

- pordıa - to sing

O porits - song sung after successful hippo hunting during cooking its meat

O pors - both the Gabbra and the Borana peoples

pua - a sp. of poisonous upside-down catfish (Synodontis frontosa): Heine (1982: 23) púà, PL púân (Chrysichthys auratus)

- pulite - very young hippo, probably one day old (Omondi and Otieno 2008: 15)

- purkus — to hide; purkus-ay ta=mpaso 'hide in the lake!'

O purkayte - dust on feet from walking

- puur, PL puurante - hair (Omondi and Otieno 2008: 15)

(- raarrst - old Egyptian goose, which lost its feathers

- ramints - beads necklace or dress of beads from the neck across the chest and armpits on both sides and worn by girls who have reached puberty (Omondi and Otieno 2008: 15)

- rarrak - necklace from ostrich egg shells given to men as a second present after arraminto when they have killed a hippo (Omondi and Otieno 2008: 15)

O raut - evening

O rekan - sharpening stone

- rengats - tomb bat

O rengeyta - stork

rete - she-goat; Heine (1980: 209) rréte

○ $r i-$ goat

- risat - Dhaasanac (cf. Reshiat)

rreck — backbone; Heine (1980: 209) rréka 'back'

O rrip - point near the gill of tilapia used to extract the intestines

rripate - dorsal fin (Heine 1982: 23: ripáte, PL ripateni)

O rrirre - cloudy, covered sky: keti ykop rrirre 'the world is covered'

rrıgo - blacksmith plover (Heine 1982: 29: rígo, PL rígôn 'wagtail species')

- rrirripate - end of the dorsal fin (v. rripate)

- rriso - moustache (Omondi and Otieno 2008: 16)

rrom - ashes; Heine (1980: 209) rrôm

rros - brain; Heine (1980: 209) rrôw

O rros - to stop the fish from leaving the net

rruf - hair (of head); Heine (1980: 209) rrúfan

- rruk - soil (Omondi and Otieno 2008: 16)

○ saakste - a sp. of white biting fly

saala — rope used in hunting hippo; Heine (1982: 28): sáála, PL saalaní

saale — woman (after circumcision); Heine (1980: 209) sáále

- saale deya - widow (Omondi and Otieno 2008: 16)

- saam - rope used for fishing (similar to kaans but shorter) (Lengosira and Lenapir 2010: 10) 
- saarad - bag (Omondi and Otieno 2008: 16); specifically: the bag containing clay from Moite in the gaante of the Marle clan

- saarma - a variety of flamingo sagal — nine; Heine (1980: 209) sáakal

O sakar - place white with bird's faeces

O sakarts - holy area which one is forbidden to tread upon with shoes

- salanka - older brother's wife

○ salapa, PL -ni - sp. of tree used for making fire sticks

- salate - appendix (Omondi and Otieno 2008: 16)

- salav - paternal aunt, uncle's wife

- salav metc - eldest maternal uncle's wife (Omondi and Otieno 2008: 16)

- salar nina - youngest maternal uncle's wife

samac — a very small tilapia; Heine (1982: 33) sámac, PL sámac-i 'baby tilapia'

- samme - piece of the net used to keep cooking fish from breaking

- saname - calf (Omondi and Otieno 2008: 16)

- sanayle - stock marabou (Omondi and Otieno 2008: 16)

sasapate - spider; Heine (1980: 209) sásápáte

O sawwe - meat of the throat of the hippo

O serrakáto - white foam remaining on stones after the water from the lake has receded seur — song performed in hippo hunting; Heine (1982: 29): sáúrr, PL saurri' 'song performed when a hippopotamus has been killed'

O scela - women's cloth

○ sczn - 1. dundruff, dry skin; 2. dust of the doum palm (Omondi and Otieno 2008: 16 have seen 'horn')

scepe — seven; Heine (1980: 209) sápa, tíipa

sccte - three; Heine (1980: 209) séépe

- sck - salty soil from the lake which animal feed on (Omondi and Otieno 2008: 16) si-v. $\operatorname{ar}(s i)$

- siima - brother's daughter (Omondi and Otieno 2008: 17 have simaa)

- siinga - metal necklace worn by Elmolo boys before the extraction of their lower teeth

(Omondi and Otieno 2008: 17)

( ) siipe - fish fat, used against fever

- sikille - clitoris (Lengosira and Lenapir 2010: 10 have sigele); narem ytito sikille 'I had intercourse with the girl'

sila - women's apron, traditionally made of doum palm fibres; Heine (1982: 30): sılá, PL sılân; cf. also Dhaasanac silla 'front part of the unmarried women's skirt' (Tosco 2001: 526)

- sinate - bladder (Omondi and Otieno 2008: 17)

- sIIp - resting house for old men, where harpoons were kept (Omondi and Otieno 2008: 17)

- silaats - compacted reeds with mud used for house sheltering (Lengosira and Lenapir 2010: 10)

šIllık - heel; Heine (1982: 31): cilik, PL cíliki 'sinew of foot'; $\boldsymbol{k}$-aaya šillık 'my heel hurts me'

○ simaders - Turkana

- sirinın - evening star (Omondi and Otieno 2008: 17); usually appears from the East in June and marks the season of rising of the water in Lake Turkana and of breeding for tortoise strrante - flamingo; Heine (1980: 209) sérrán-te 
sokan — dorsal fin; Heine (1982: 33): sókan, PL sókaní

○ solac - dove

sonkolaite - hermaphrodite crocodile; Heine (1982: 27): songvlaité 'impotent crocodile'

soo - meat; Heine (1980: 209) sóo

O sskays - bark of tree

O solassla - name of a song asking for the wind to blow

somst, sommants - lungs; Heine (1980: 209) sómot

səons - nose; upper part of fish when cut; Heine (1980: 209) sóóno

- sosns kulac — wind with dry hot air

- ssoy - brother-in-law (Omondi and Otieno 2008: 17 'any male in-law')

- sorika - algae (Omondi and Otieno 2008: 17)

suke - lateral fin; Heine (1982: 23): súke, PL súkên 'pelvic fin'

- $s v d d \varepsilon-\mathrm{sp}$. of tree used in the construction of the house, coming from Moite mountain

(Samburu loom)

O sukkan, PL sukkanni - each of the joints of the dorsal fin

O sor - clay from Moite, taken to the gaante shrines for magical purposes

O sursur - a sp. of fish, similar to arte

sơm - early morning; Heine (1980: 209) súum

O sovtI - mat used to cover the house from rain

- taa - electric catfish (Malapterurus electricus); Heine (1982: 23): táà, PL táál 'puffer'

(Tetraeodon fahaka)

- taaka - one (v. tooko) (Omondi and Otieno 2008: 17)

taats - Egyptian goose (Alopochen aegyptiaca); Heine (1980: 209) tééto

- talmane, talmanini early dawn, about 5 a.m. (Omondi and Otieno 2008: 17); Southern Cross, star which normally appears from the East in August and marks the season of no breeding; name of two months in July and August

- tam - Nile perch back part of the belly (v. apap)

- tamate - name of an insect which eats the raft

- tambs - tobacco

tamots - small tilapia; Brenzinger (1992: 247) tamúto, PL tamutoní

○ tarram - to collect dirt; tarram-a neniá mutún 'cover that firewood!;' specifically: to collect dirt in order to cover its eggs (subj.: tortoise)

teric - baboon; Heine (1980: 204) dérric

○ t $t w$, PL -In - shelter beside the house; m-aape awcni t $\varepsilon$ - $t \varepsilon w$ 'let's go sit in the shelter'

- tian - February star which normally appears from the East and marks the season of heavy rains and breeding of crocodiles (Omondi and Otieno 2008: 18)

- tipe - spinal cord

tıkIr - giraffe catfish (Auchenoglanis occidentalis) or upside-down catfish (Synodontis schall);

Heine (1980: 209) tikir

tıpır - navel; Heine (1980: 209) tipir

tıra - liver; Heine (1980: 209) tíra

- trrms, PL tirmoni - string ornament worn on the wrist by men and on the leg by women

(Omondi and Otieno 2008: 18)

- togolac - goat's droppings (Omondi and Otieno 2008: 18 have toklash) 
tooko - one; Heine (1980: 209) tóko, táka

tom๖n - ten; tomon taaka 'eleven;' tomon lama 'twelve;' tomon lam 'twenty;' tomon lam yii 'twenty-six;' Heine (1980: 209) tómon

to̊f - snake; Heine (1980: 209) tóof

○ toska - to float; $\boldsymbol{k \varepsilon - t \jmath \jmath k a ~ ' i t ~ f l o a t s ; ' ~} \boldsymbol{k \varepsilon}$-tıoka lkinay ta-mpaso 'a crocodile is floating in the lake;' ano toska lkinay 'when is the crocodile floating?;' ana-toska 'it is floating;' nenia jinte na-toska 'there is a Nile perch floating'

O tosm - camel fat

toor - harpoon; Heine (1982: 33) toor, PL tôrrí

( ) tosr bovte - fish harpoon

○ toor naud, toor poorte — crocodile harpoon

- tosre sala - harpoon for hunting hippo (Omondi and Otieno 2008: 18)

- torlac - general name for fish of the yost kind torr - compost pit; Heine (1982: 29) tor 'a heap of rubbish'

- torrac - name of a star

- tulala - scorpion tumalak - blacksmith; Heine (1980: 209) túmalac

tuwate - Nile puffer (inedible fish; Tetraodon lineatus or fahaka strigosus); Heine (1982: 23): túúwáte, PL tuuwatení

tomante, PL -ni - rib; Heine (1980: 209) túmánte

- tons - grandmother (Lengosira and Lenapir 2010: 11)

top - lower part of buttocks; Heine (1980: 209) tûp 'buttock, tail'

- toriy - strong wind (Omondi and Otieno 2008: 18)

unuf - rope, in particular used with the harpoon in hunting hippos; Heine (1980: 210) únuf'lightcoloured rope for catching hippos and crocodiles'

urat - Nile perch skin, also used for covering, esp. by men (made of oryx hide for the Marle men); Heine (1980: 210) úrat

- urrac — root of the kilpayte, used against fever or stomach problems

○ uruk - fat part of dry fish soup ( $\varepsilon r r)$, which is filtered down

urup - mudfish (Heine 1982: 27: úrup, PL úrupi)

- of, -in - upper part of buttocks (Omondi and Otieno 2008: 18); fat part of fresh fish soup, which is filtered

- vnor - the fat part in the stomach of the hippo (Omondi and Otieno 2008: 19)

op - hand, arm; Heine (1980: 210) ûp

- vrgate - joints disease

vrr - faeces of fish; Heine (1980: 210) úrr

- vrrac - sp. of shrub (Samburu l-dagesi)

- vrro - down

O vryan - black ant

- orm - early evening (Omondi and Otieno 2008: 19)

- owate - plate made of clay and only used by women who have given birth (Omondi and Otieno 2008: 19)

waak - god; waak apa 'god of (our) fathers'; Heine (1980: 210) wáak 
waak anufa - good night (greeting; reply: hayye)

- waaka parite - good morning (greeting; reply: oni marige 'I slept well') (Omondi 2008: 30:

akaparite)

○ waar - land protruding from the water

wale - pelican; Heine (1980: 210) wále

- wanufa - good night (greeting, also reply) (Omondi 2008: 30)

- waram - to fish at moonlight (the same as ajia?); kai-warama 'I am fishing at moonlight;'

kalo ai-warama 'I am going to fish at moonlight;' $i$-waramai 'fish at moonlight!;' ai-

waramai 'fish (PL) at moonlight!;' mi-warama 'do not fish at moonlight!;' ami-warama

'do not fish (PL) at moonlight!'

○ wawate - water reeds used for thatching the house (Samburu gerei)

○ yaako - father

yaalla - friend; Heine (1980: 210) yál

○ yaam - fat of tortoise

○ yaar - troublemaker; m-i-kiyeki yaar 'do not befuddle me with your talking!'

yaarro - plover; Heine (1980: 210) yárro

- yakat - green grass (Omondi and Otieno 2008: 19)

- yapar - sp. of tree used in the construction of the house, coming from Loiyangalani; name of

Loiyangalani

yapite - heavy clouds that normally result in rain; Heine (1980: 210) yáp-te 'cloud, rainbow'

○ yardu - to fetch

yargote, PL yargoteni - fish tail; Heine (1982: 23) yarkóte, PL yarkotení

yarks - cow or donkey dung/droppings; Heine (1980: 210) yárgo

○ yaupo - a type of big yaarro, not as big as killa

yee - hippo; Heine (1980: 210) yê

○ yeef - skin around the mouth of fish

- yeren - nape (Omondi and Otieno 2008: 19 have yeren for both yeren and yeren)

yete — female hippo; Heine (1980: 210) yê-te

- yeyate - mat used to cover the house for shade or for sleeping (Lengosira and Lenapir 2010:

11: yeyato)

○ yeyato - spoon-billed stork

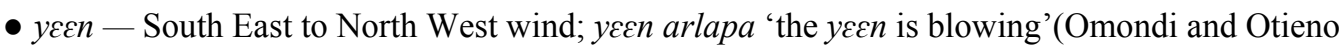

2008: 20)

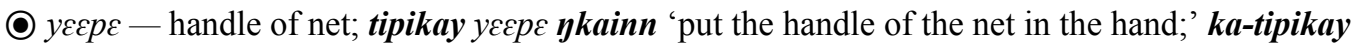

уєсре пkainay 'I put the handle in my hand'

yєere — knife; Heine (1980: 210) yérre

- yeges - to pull (Omondi and Otieno 2008: 20)

- yersn - neck; nape of hippo (Omondi and Otieno 2008: 20)

- yergI - to twirl (Omondi and Otieno 2008: 19 translate: 'strong wind which causes cyclic

movement of water (in lake)'); $\boldsymbol{k a}$-yergi-se lkinay 'the crocodile is making a twirl under

water'

yergv — mango tilapia (Tilapia zillii) (Heine 1982: 22: yérgu, PL yérgûn)

O yerps - soft meat in the crocodile's chest

yese - I; Heine (1980: 210) yesé 
yii-six; Heine (1980: 210) yii

yoloda - good; Heine (1980: 210) yólo-da

yəs - long paddle with a broad blade at both ends used for deep and sideways paddling of the rafts in deep waters; Heine (1982: 28) iyô, PL iyôni

- yos garto - short paddle with a broad blade at one end used for paddling the raft on both sides in turn (Omondi and Otieno 2008: 20)

yost - a sp. of lutefish (Citharinus citharus intermedius); Heine (1982: 23) yóot, PL yóotí

- yorsk - each one of the horizontal strips dividing the sila

() $y \sigma-$ root

O youro - taboo (on fish, e.g., bisecting the kingfish (kaara) or drying the tigerfish (koriis), or cooking together kingfish and catfish (tIkIr) or Nile perch (iji), or cutting fish before

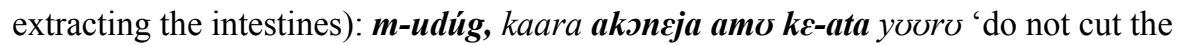
kingfish like that, because it is taboo!'

Mauro Tosco

mauro.tosco@unito.it
Submitted: 20 July 15

Accepted: 26 Aug 15

Revisions: 1 Sept 15 
